NBER WORKING PAPER SERIES

\title{
DEBT RELIEF: WHAT DO THE MARKETS THINK?
}

\author{
Serkan Arslanalp \\ Peter Blair Henry \\ Working Paper 9369 \\ http://www.nber.org/papers/w9369 \\ NATIONAL BUREAU OF ECONOMIC RESEARCH \\ 1050 Massachusetts Avenue \\ Cambridge, MA 02138 \\ December 2002
}

We thank Jeremy Bulow for helpful conversations and Rania A. Eltom for able research assistance. Henry gratefully acknowledges financial support from an NSF CAREER Award and the Stanford Institute for Economic Policy Research (SIEPR). The views expressed herein are those of the authors and not necessarily those of the National Bureau of Economic Research.

(C) 2002 by Serkan Arslanalp and Peter Blair Henry. All rights reserved. Short sections of text, not to exceed two paragraphs, may be quoted without explicit permission provided that full credit, including (C) notice, is given to the source. 
Debt Relief: What Do the Markets Think?

Serkan Arslanalp and Peter Blair Henry

NBER Working Paper No. 9369

December 2002

\section{$\underline{\text { ABSTRACT }}$}

The stock market appreciates by an average of 60 percent in real dollar terms when countries announce debt relief agreements under the Brady Plan. In contrast, there is no significant increase in market value for a control group of countries that do not sign agreements. The results persist after controlling for IMF agreements, trade liberalizations, capital account liberalizations, and privatization programs. The stock market revaluations forecast higher future net resource transfers and GDP growth. While markets respond favorably to debt relief in the Brady countries, there is no evidence to suggest that current debt relief efforts for the Highly-Indebted Poor Countries (HIPCs) will achieve similar results.

Serkan Arslanalp

Stanford University

Department of Economics

Landau Economics Building

579 Serra Mall

Stanford, CA 94305-6072

serkan@stanford.edu
Peter Blair Henry

Stanford University

Graduate School of Business

Stanford, CA 94305-5015

and NBER

pbhenry@stanford.edu 


\section{Introduction}

Bono and Jesse Helms want debt relief for highly indebted poor countries (HIPCs). The Pope and 17 million people are behind them. On June 17, 1999, the lead singer of U2 presented 17 million signatures in support of the Jubilee 2000 Debt Relief Initiative to Chancellor Gerhard Schroeder at a meeting of G8 leaders in Cologne, Germany. In a Papal Bull on November 29, 1998, Pope John Paul II called on wealthy nations to relieve the debts of developing nations in order to "remove the shadow of death."

Opponents of debt relief occupy less hallowed ground but are no less zealous about their cause, citing at least three reasons why the debt relief campaign is misguided. First, debt relief alone cannot solve the problem of third world debt. Even if all debt were forgiven, it will accumulate again if income does not grow faster than expenditure (O’Neill, 2002). Second, debt relief can create perverse incentives for debtor countriesby relaxing budget constraints, debt relief may induce governments into prolonging bad economic policies (Easterly, 2001a). Third, rewriting debt contracts may hurt a debtor's reputation and hinder its ability to obtain future loans (Easterly, 2001b).

Moral proponents of debt relief can point to three counterarguments in their defense. First, some debts are illegitimate. There is a precedent for canceling debt that is odious - incurred without the consent of the people and not for their benefit- and Kremer and Jayachandran (2002) present a feasible way of doing so. Second, debt relief can benefit both creditors and debtors (Krugman, 1988; Sachs, 1989). Third, and related to the second point, it is good accounting practice to write off debts that cannot be 
collected. That way, future loans can be given on a sounder economic basis (Sachs and Huizinga, 1987; Summers, 2000).

Does debt relief help or hurt the recipient? This paper takes a new approach. We ask the stock market to opine. In March of 1989 the United States government formally approved an initiative by Treasury Secretary Nicolas Brady calling for debt relief for third world countries. Between 1989 and 1995, sixteen developing countries reached debt relief agreements under the Brady plan. This paper examines the response of each debtor country's stock market to the news of its own Brady agreement. Figure 1 conveys the central fact. The stock market appreciates by an average of 60 percent in real dollar terms when countries announce the signing of a Brady debt relief agreement.

The stock market is forward looking. It asks what discount rates and cash flows lie ahead. The effect of debt relief on discount rates and cash flows follows from the collective action problem that it is designed to solve. If each creditor would agree to forgive some of its claims, then the debtor country would be better able to service the debt owed to each creditor. Consequently, the expected value of all creditors' claims would rise. Forgiveness will not happen without coordination, however, because any individual creditor would prefer to free ride, maintaining the full value of its claims while others write off some debt (Krugman, 1988; Sachs, 1989). By forcing all creditors to take a haircut, debt relief solves the collective action problem and paves the way for profitable new lending (Cline, 1995). The new capital inflow reduces discount rates in the debtor country by relaxing the intertemporal budget constraint (Obstfeld and Rogoff, 1996). Also, to the extent that a country suffers from debt overhang, debt relief increases 
the incentive to invest and may raise expected future growth rates and cash flows (Krugman, 1989; Sachs, 1989).

The stock market removes the temporal dimension of the analysis by collapsing the entire expected future stream of debtor-country discount rates and cash flows into a single summary statistic: the change in the value of the stock market. However, it is important not to look at debtor-country stock market responses in isolation. Suppose that the Brady Plan coincides with a global shock unrelated to debt relief that reduces discount rates and increases cash flows. Debtor-country stock markets will rise, but so too will stock markets in countries that do not sign debt relief agreements.

In order to assess whether the Brady country stock market boom was due to the announcement of debt relief agreements or a common shock, we compare the stock market response of the Brady countries with the market response of a similar group of countries that did not sign Brady deals. Figure 1 shows that the control group does not experience a significant increase in stock prices; the market response in debtor countries cannot be explained by an unobservable common shock.

Reporting the results in real dollar terms also requires caution. In countries with high inflation, the rate of depreciation of the official nominal exchange rate may not keep pace with inflation. Under such a scenario, the real dollar value of the stock market may become artificially inflated. To account for this possibility, Section II analyzes the stock market using real local-currency stock returns. The conclusions are unaltered. The stock market responds in a positive and statistically significant manner to debt relief agreements, but there is no significant market response for the control group. 
Many countries enter into IMF programs immediately following the announcement of their Brady Plan. Therefore, it is possible that debt relief agreements drive up stock prices because they signal future IMF programs. We investigate this possibility by examining whether stock markets respond positively to IMF agreements that are not accompanied by debt relief. Section IV demonstrates that this is not the case.

Similarly, countries receive Brady deals in return for committing to economic reforms that are designed to increase openness and raise productivity. So, it is possible that stock prices go up because debt relief signals future reforms. Again, this is not the case. The market response to debt relief remains significant when controlling for concurrent reforms: trade liberalization, privatization, and capital account liberalization.

After grappling with concerns about robustness in Section IV, Section V turns to issues of interpretation. Why do stock prices rise? Is this a spurious result? Or, does the stock market rationally forecast future changes in future fundamentals? Again, theory points to the net resource transfer (NRT) and future growth. If market values rise because debt relief paves the way for profitable new lending, then the stock market responses should have some predictive power for future changes in the NRT. Similarly, if debt relief improves future growth prospects, then the stock market responses should have some predictive power for future changes in output. While this approach does not provide definitive evidence, the stock market responses do help predict the change in the NRT and GDP growth for up to five years following the agreements.

Would debt relief for the HIPCs produce the salutary effects achieved by the Brady Plan? We do not think so. The Brady Plan worked because debt relief was the appropriate policy response for a group of countries where the collective action problem 
genuinely stood in the way of profitable new lending. In a companion paper, we demonstrate that the collective action problem is not the primary obstacle to growth in the HIPCs (Arslanalp and Henry 2002). Rather, the principal obstacles are a lack of basic institutions and social infrastructure, problems that debt relief is unlikely to solve (Easterly 2001b)

Debt relief has become synonymous with the HIPCs, but a number of middleincome developing countries are also substantially indebted (Easterly 2001b; Birdsall and Williamson 2002). Furthermore, Section VI of this paper shows that these middleincome countries bear far greater resemblance to the Brady countries than do the highly indebted poor countries. And yet the middle-income debtors are not part of the debt relief conversation. In other words, our results point to a cruel irony. The debt relief debate focuses myopically on the HIPCs, whose problems debt relief cannot solve, while countries that would actually benefit from debt relief receive precious little consideration.

\section{Data and Descriptive Findings}

Table I provides a complete list of the countries in the treatment and control groups. The treatment group consists of all countries that received a Brady Plan. There are 16 such countries: Argentina, Bolivia, Brazil, Bulgaria, Costa Rica, the Dominican Republic, Ecuador, Jordan, Mexico, Nigeria, Panama, Peru, the Philippines, Poland, Uruguay, and Venezuela. The table also gives the announcement date of each country's Brady Plan. The principal source of dates is Table 5.3 on page 234 of International Debt Reexamined (Cline, 1995). However, the book does not provide announcement dates for 
Bolivia, Nigeria, Panama, Peru and the Philippines ${ }^{\square}$. For these five countries we retrieved announcement dates using the Lexis-Nexis Academic Universe http://web.lexis-nexis.com/universe ${ }^{2}$ We verified the accuracy of the search by matching the dates obtained from Lexis-Nexis with those in the Quarterly Economic Reports of the Economist Intelligence Unit (EIU).

\section{IIA. Selection of the Control group}

The control group consists of all developing countries that: (1) Did not receive a Brady plan; and (2) Have stock market data in the International Finance Corporation (IFC) Emerging Market Data Base going back to at least 1994. There are 16 such countries: Chile, China, Colombia, the Czech Republic, Greece, Hungary, India, Indonesia, Korea, Malaysia, Pakistan, South Africa, Sri Lanka, Thailand, Turkey, and Zimbabwe.

Since the treatment group consists of countries whose stock markets respond to external shocks, it is crucial that the control group contains countries whose stock markets will also respond to such shocks. If the control group consists of countries in such an abject state of development that their economies lack basic institutions, then their stock markets may not respond positively no matter how favorable the external shocks. In other words, it is important to ask whether the selection of the control group introduces statistical bias into our findings. We address this concern by examining the characteristics of the two groups in some detail.

\footnotetext{
${ }^{1}$ Cline (1995) provides only the year of the announcement for the Philippines and only the implementation date for Nigeria and Bolivia. It does not provide any dates for Panama and Peru because these countries were still negotiating their debt relief agreements at the time of the publication.

${ }^{2}$ A data appendix containing the complete list of articles that were uncovered by the Lexis Nexis search is available upon request.
} 
The treatment group and the control group display similar geographical dispersion. Both groups contain countries from Latin America, Asia, Africa, and Eastern Europe. One significant difference is that Latin American countries comprise the largest fraction of countries in the treatment group. The control group, however, consists mostly of Asian counties. History suggests that the relatively heavier weighting of Asian countries in the control group will make that group the stronger economic performer. We confirm this suspicion by comparing the treatment group and the control group using two standard measures of economic performance, growth and inflation.

The control group outperforms the treatment group on both measures. Table I shows that between 1980 and 1999 the median growth rate of per capita GDP for the control group was 3 percent. The treatment group grew by only 1 percent per year during the same time period. GDP growth was also less volatile in the control group. The standard error of GDP growth for the control group was 1 percent, as compared to 2 percent for the treatment group. Finally, the control group has a lower and less volatile rate of inflation: a median of 11 percent and a standard deviation of 3 percent. The corresponding numbers for the treatment group are 27 and 18.

To summarize, the median country in the control group has faster and less volatile growth together with lower and less volatile inflation than its treatment group counterpart. To the extent that superior long-run economic performance is positively correlated with better-managed economies, we would expect stock markets in the median control-group country to be more responsive to any auspicious common shock. If there is any selection bias, it works against finding a significantly large revaluation in the Brady countries. In other words, the bias, if any, strengthens our results. 


\section{IIB. Stock Market Data}

The principal source of stock market data is the IFC's Emerging Markets Data Base (EMDB) ${ }^{3}$. Stock price indices for individual countries are the dividend-inclusive, U.S. dollar-denominated and local currency-denominated IFC Global Indices. For most countries, EMDB's coverage begins in December 1975, but for others coverage only begins in December 1984. Each country's U.S. dollar-denominated stock price index is deflated by the U.S. consumer price index (CPI), which comes from the IMF's International Financial Statistics (IFS). The local currency-denominated index is deflated by the local consumer price index for each country, which is also obtained from the IFS. Returns and inflation are calculated as the first difference of the natural logarithm of the real stock price and CPI, respectively. All of the data are monthly.

Reliable stock market data exist for only 10 of the Brady countries: Argentina, Brazil, Ecuador, Jordan, Mexico, Nigeria, Peru, the Philippines, Poland, and Venezuela. We bring back Bolivia, Bulgaria, Costa Rica, Dominican Republic, Panama, and Uruguay into the picture in Section $\mathrm{V}$ where we move the focus of analysis from financial to real data.

\section{IIC. Descriptive Findings: Stock Market Responses to Debt Relief Announcements}

This subsection presents evidence on how the stock market responds to news of a future debt relief agreement. For each country in the treatment group we calculate the average monthly stock return over the entire sample. The average monthly return is a proxy for the expected monthly return. Subtracting a country's expected return from its actual return gives the abnormal return. Now let month [0] be the month in which a

\footnotetext{
${ }^{3}$ For Ecuador, the source of stock market data is the Global Financial Data Base.
} 
Brady debt relief announcement takes place, for a given country. Similarly, let [-12] denote the $12^{\text {th }}$ month before the debt relief announcement, so that $[-12,0]$ denotes the one-year window preceding the announcement. The cumulative abnormal return for a country is defined as the sum of its abnormal returns from month -12 to month 0 .

Figure 1 plots the average cumulative abnormal return across all ten Brady countries in event time. The average Brady country stock market experiences cumulative abnormal returns of 60 percent in real dollar terms. In other words, the real dollar value of the stock market increases by 60 percent more than it does in a typical year. Now look at the graph for the control group. If a common shock caused the run-up in equity prices in the Brady countries, then we should see a run-up in the stock prices of the control group as well. This is not the case. The average cumulative abnormal return for the control group is close to 0 . The preliminary conclusion is that the stock price increase in the debtor countries is not due exclusively to a common shock that has favorable effects on all emerging stock markets.

One concern is that the results may be sensitive to whether real returns are measured in dollars or local currency units. To address this concern, Figure 2 replicates the graph using real local currency returns instead of real dollar returns. Figure 2 is virtually identical to Figure 1 . Since the choice of currency makes little difference, the formal empirical analysis in Section III focuses on the dollar-denominated returns.

Outliers are another source of potential concern. Since there are only ten countries in the Brady stock market group, one country may dominate the results. To explore this possibility we conduct median tests in the following way. For each of the ten countries we compute the median annual stock return. The stock return in the 12-month 
period preceding the Brady announcement exceeds the median, annual return for every country except Peru. We also conducted median tests in local currency and the results were the same. Peru is the only country whose stock return during the 12-month announcement window was less than its median 12-month return.

\section{Methodology and Formal Empirical Results}

We evaluate the statistical significance of the relationships apparent in Figure 1 by estimating the following regression:

$$
R_{i t}=\alpha_{i}+\gamma_{1} B_{R A D Y}+\gamma_{2} \text { CONTROL }_{i t}+\varepsilon_{i t} .
$$

Where $R_{i t}$ is the real return in dollars on country $i$ 's stock market index in month $t$, $B R A D Y_{i t}$ is a dummy variable that is equal to one in $[-12,0]$. CONTROL is a dummy variable that is equal to one in all of the control countries in Brady-Announcement months $[-12,0]$. We also estimate BRADY and CONTROL using nine-month $[-9,0]$, six-month $[-6,0]$, and three-month $[-3,0]$ windows. The country-specific intercepts allow for the possibility that average expected returns may differ across countries due to imperfect capital market integration.

Equation (1) constrains the coefficients on BRADY to be the same across all months, which means that the parameter $\gamma_{1}$ measures the average monthly stock market response to all Brady Plan Announcements. Since the dummy variable for the event window is twelve months long, the total stock market response to debt relief for the Brady countries is given by twelve times the parameter estimate.

A different estimation technique would be to use a seemingly unrelated regression (SUR). This approach would have the advantage of providing a unique coefficient 
estimate for each country for each event. However, there are also disadvantages to this approach. The low power of hypothesis tests in unconstrained systems severely weakens the ability of the event study methodology to detect the impact of the event. Second, SUR requires a balanced panel. Due to the limited time series availability of stock market data, creating a balanced panel would result in discarding some of the 10 debt relief events. Given data limitations, the pooled cross-section time series framework seems appropriate.

With an unbalanced panel, it is not possible to relax the assumption of no contemporaneous correlation of the error term across countries. Therefore, we will take indirect precautions. Specifically, three of the alternative regression specifications to equation (1) will estimate abnormal returns relative to the World stock market index, US stock market index, and finally IFC's emerging stock market index. Since all of the sample countries are emerging markets, the inclusion of a composite emerging market index as a right-hand-side variable will partially control for contemporaneously correlated disturbance terms. Including the emerging market index does not change the results.

\section{IIIA. Basic Results}

The first row of Table II (Panel A) - labeled 'Country-Specific Mean' - gives the results from the baseline specification in equation (1). White standard errors are reported in parentheses. Column (1a) shows that the coefficient on BRADY for the twelve-month window $[-12,0]$ is 0.05 and is statistically significant at the 1 percent level. Multiplying the coefficient by 12 gives the total effect, a 60-percent increase in the real 
dollar value of the stock market. Column (1b) gives the coefficient estimate for the CONTROL dummy. In contrast to the estimate for the BRADY countries, the revaluation effect associated with the control group is economically weak, 0.005, and statistically insignificant. Column (1c) provides the p-value from a two-sided F-test of the hypothesis that the coefficient estimate on BRADY is equal to the coefficient estimate on CONTROL. The p-value for this test is 0.001 . The difference between the BRADY estimate and the CONTROL estimate is statistically significant. In other words, the stock market in BRADY countries rises by roughly 60 percentage points more than it does in the CONTROL group.

The results using nine-month, six-month, and three-month windows are all consistent with the 12-month estimates. The coefficient estimate of BRADY ranges from 0.048 to 0.052 and is statistically significant in every specification. Furthermore, the BRADY estimate is always significantly larger than the estimate of CONTROL. Row 2 of Table II (Panel A) — labeled, 'Constant Mean' - presents estimates of equation (1) using a constant intercept term, $\alpha$, instead of country-specific intercept terms. The results are almost identical to those in Row 1.

\section{IIIB. Controlling For World Stock Markets}

Equation (1) provides a parsimonious baseline specification of abnormal returns, but it does not allow for the influence of world stock markets on local returns. In order to do so, we follow Kho, Lee and Stulz (2000) and use the international capital asset pricing model (ICAPM) to measure the expected return on each country's stock market index. Specifically, we now estimate: 
$R_{i t}=\alpha_{i}+\beta R_{t}^{W}+\gamma_{1} B R A D Y_{i t}+\gamma_{2} C O N T R O L+\varepsilon_{i t}$,

Where $R_{t}^{W}$ is the real return in dollars on the Morgan Stanley Capital Market Index

(MSCI) in month $t$. While barriers to the international movement of capital may raise questions about the economic assumption of an ICAPM, as a purely statistical matter, returns on world stock market indices do have some predictive power for stock returns in the countries under consideration (Henry 2000a).

Row 3 of Table II (Panel A) presents estimates of BRADY and CONTROL using equation (2). Row 4 presents estimates that use real U.S. stock returns, $R_{t}^{U S}$, in place of $R_{t}^{W}$. Row 5 presents estimates that use the real dollar return on the IFC Emerging Market index, $R_{t}^{L D C}$, in place of $R_{t}^{W}$. Row 6 presents estimates that use all three sets of world stock returns simultaneously. The results in Rows 3 through 6 perfectly mirror those under the benchmark specification in Rows 1 and 2. The coefficient on BRADY is statistically significant under all four ICAPM specifications. The point estimate ranges from 4.9 to 3.9 percent per month, and the estimate of BRADY is significantly larger than the estimate of CONTROL in all but the three-month window estimates.

\section{IIIC. Other Robustness Checks}

The estimates in Panel A of Table II adjust for cross-country heteroscedasticity and cross-country correlation, but they do not account for potential serial correlation in the error terms. Hence, White standard errors may not be sufficient to ensure the

\footnotetext{
${ }^{4}$ For conceptual discussions of the international capital asset pricing model see Frankel (1994); Stulz (1999a); Tesar (1999); Tesar and Werner (1995); and Tesar and Werner (1998). For empirical evidence on the real effects of increased capital market integration, see Henry (2000b).
} 
reliability of the estimates in Panel A. To address this concern, Panel B of Table II reestimates all of the specifications in Panel A using Feasible Generalized Least Squares (FGLS). FGLS allows for the possibility of serial correlation, in addition to correcting for cross-country heteroscedasticity.

The estimations using FGLS yield the same conclusions as the OLS estimates in Panel A. Every FGLS point estimate of BRADY in Panel B of Table II is statistically significant. The FGLS monthly point estimates of BRADY are smaller than those obtained using OLS, but they are still large. The smallest point estimate for the twelvemonth window is 0.034 - a total revaluation of greater than 40 percent. Furthermore, the coefficient on BRADY remains significantly larger than the coefficient on CONTROL in all of the specifications except for some of those that use 3-month windows.

\section{Do IMF Programs and Economic Reforms Drive the Results?}

Three central facts emerge from Sections II and III: (1) Stock markets in debtor countries experience a positive and statistically significant revaluation in response to news of debt relief; (2) the effect is large and it is not an artifact of the currency in which the revaluation is measured; and (3) the response is uniformly positive across debtor countries.

The control group also experiences a mild revaluation, but the 50-percentagepoint difference between the estimates of BRADY and CONTROL is statistically significant and cannot be explained by a common shock. Having ruled out common shocks as an explanation, the following subsection of the paper examines whether the 
Brady countries' stock market revaluations are driven by the prospect of debt relief or the expectation of future IMF programs and economic reforms.

\section{IVA. IMF Programs}

Countries receive debt relief in return for agreeing to commit to economic reforms that are designed to increase openness and raise productivity (Cline, 1995). In other words, Brady agreements may also constitute implicit news about the entire future schedule of economic reforms. Official country agreements with the International Monetary Fund illustrate the point. Column 3 of Table III shows that an official agreement with the IMF immediately precedes, or follows on the heels of, every Brady deal.

Since IMF programs followed all of the Brady agreements, Brady agreements may drive up stock prices because they signal future IMF agreements. Because every debt relief agreement closely coincides with an IMF agreement, we cannot disentangle the debt relief effect by inserting into equation (3) a dummy variable for IMF programs that coincide with debt relief announcements. An IMF dummy constructed in that way would be collinear with the BRADY dummy and present the attendant econometric problems.

Therefore, we adopt a different tack. We examine whether the stock market responds to IMF agreements that are not accompanied by debt relief. We do this by constructing for each country a list of all IMF programs that did not occur within a year (before or after) of the announcement of its Brady debt relief agreement. We then create 
a dummy variable, IMFPROGRAM, which takes on the value one for all such programs, and estimate the following regression:

$$
R_{i t}=\alpha+\beta R_{t}^{W}+\gamma_{1} \operatorname{IMFPROGRAM}_{i t}+\varepsilon_{i t}
$$

Following the earlier specifications, we estimate twelve-month, nine-month, six-month, and three-month windows. If the stock market responds positively to IMF agreements that are not accompanied by debt relief, then the estimate of $\gamma_{1}$ should be positive and significant.

There is no evidence that the stock market responds positively to IMF agreements that are not associated with a Brady Debt Relief Agreement. The coefficient estimate of IMFPROGRAM is negative and statistically insignificant in every specification. The estimate for the twelve-month window is -0.016 ; the estimate for the nine-month window is -0.011 ; the estimate for the six-month window is -0.004 ; the estimate for the threemonth window is -0.027 .

\section{IVB. Economic Reforms}

Just as debt relief agreements may signal future IMF agreements, IMF agreements may in turn signal countries' commitment to future economic reforms (Williamson, 1994; Collins, 1990; Bruno and Easterly, 1996). By transitivity, debt relief may signal future economic reforms. If debt relief agreements are a signal of future productivity-enhancing reforms, then the results in Table II may erroneously attribute the stock market revaluation to debt relief instead of the future reforms.

\footnotetext{
${ }^{5}$ The insignificance of the IMFPROGRAM variable is consistent with evidence that the market responds positively to IMF agreements, only when they are announced in the midst of high inflation (Henry, 2002).
} 
Columns 2 through 4 of Table III present a list of critical economic reform dates in each country. Broadly speaking, economic reforms fall into one of four areas: stabilization, privatization, trade liberalization, and capital account liberalization. The previous subsection on IMF programs addresses stabilization issues. This subsection focuses on the latter three reforms.

We use the Economist Intelligence Unit's Quarterly Economic Reports to identify the date of trade liberalization. We check the EIU dates against the trade liberalization dates in the World Bank Publication, Trends in Developing Economies (1994) and the dates in Sachs and Warner (1995). We identify privatization dates with the World Bank Privatization Transaction Database, which contains the names and dollar amounts of all privatizations occurring between 1988 and 1999 . We use the database to identify the first year in which there were recorded sales of stated owned enterprises. Once we know the year of the first sale, we search the EIU's quarterly economic reports for the month in which the start of the privatization program was announced. We also check the EIU to make sure that there were no privatizations preceding the starting date of the database. Finally, the capital account liberalization dates come from Henry (2000).

A close examination of Table III illustrates the point of the exercise. All of the treatment countries began implementing major economic reforms before, during and after the Brady period. There is sufficient heterogeneity (staggering) in the timing of the economic reforms to allow us to control directly for their effect on stock prices. To do so, we construct a series of reform dummies for each country: TRADE; PRIVATIZE; LIBERALIZE. These variables take on the value 1 during the month a reform is 
announced and in each of the preceding 11 months. We then estimate the following regression:

$R_{i t}=\alpha_{i}+\beta R_{t}^{W}+\gamma_{1} B_{R A D Y_{i t}}+\gamma_{2}$ CONTROL $_{i t}+\gamma_{3}$ TRADE $_{i t}+\gamma_{4}$ PRIVATE $_{i t}+\gamma_{5}$ CAPITAL $_{i t}+\varepsilon_{i t}$ (5)

Table IV presents the results. Panel A gives the White-corrected OLS estimates. Panel B gives the FGLS estimates. The coefficient on BRADY is significant at the 1 percent or 5 percent level for every window. The point estimate of 0.05 suggests an average revaluation of 5 percent per month during the debt relief announcement window. The third row of the table shows that the coefficient on BRADY is significantly different from the coefficient on CONTROL for all of the specifications. Consistent with a number of previous papers, the capital account liberalization dummy is significant for the $[-6,0]$ and $[-3,-1]$ windows. There is little evidence that the other reforms do much to stock prices during the sample period. Table IV suggests that the Brady Plan is an important source of market revaluation, even after controlling for the effect of contemporaneous economic reforms.

\section{IVC. Is it a Halo Effect?}

Since we find no significant effect of real economic reforms, it is important to ask whether the documented rise in stock prices associated with the Brady Deal is spurious. In other words, is there a temporary halo effect associated with Brady countries, a kind of irrational exuberance about the efficacy of debt relief that is not justified by subsequent changes in the fundamentals? Two pieces of evidence suggest that this is not the case.

First, although the point estimates of the market responses to reforms are not significant, it does not follow that economic reforms are unimportant. On the contrary, 
economic reforms are an essential complement, which help ensure the viability of debt relief agreements. Figure 3 illustrates the point. In the three countries in which reforms stalled temporarily - Jordan, Nigeria, and the Philippines - the initial rise in valuations is completely wiped out. In other words, debt relief does little good unless it is accompanied by real changes that alter a country's underlying economic fundamentals.

Second, ex-post evidence suggests that the stock market revaluations are not simply a halo effect. Specifically, the next section of the paper demonstrates that the stock market accurately forecasts changes in real fundamental variables such as GDP growth and the Net Resource Transfers (NRT). In particular, high GDP growth, and positive NRTs follow after all stock market revaluations.

\section{Exploring the Fundamentals: Why Do Market Values Rise?}

If the stock market increases are not spurious, they should reflect a fall in future discount rates and or a rise in cash flows. Accordingly, this section of the paper examines the extent to which the ex-ante changes in market valuation rationally forecast ex-post changes in discount rates and cash flows.

The effect of debt relief on discount rates follows from the collective action problem that debt relief is designed to address. To understand the collective action problem it is useful to introduce the idea of the net resource transfer (NRT). The NRT is the net flow of real resources into a country, and therefore has direct implications for discount rates. 6

\footnotetext{
${ }^{6}$ Discount rates in developing countries are notoriously hard to measure. Financial repression and other market distortions, which characterized these countries prior to the Brady Plan, make it difficult to assess the true change in the risk-free rate from official interest rates. Instead of looking at official interest rate measures, which may not reflect the true scarcity of capital, we use the change in the NRT as a proxy.
} 
As rich countries with high capital to labor ratios will export capital to poor countries where the rate of return is higher, poor countries typically experience positive NRTs. However, the NRT may suddenly turn negative when collective action problems arise - adverse shocks or poor economic management may drive risk averse creditors to call in existing loans and make potential new creditors unwilling to lend. Since lending would be profitable if not all creditors tried to get their money at once, the negative NRT outcome is inefficient. By forcing all creditors to take a haircut, debt relief solves the collective action problem and paves the way for profitable new lending (Cline, 1995). The new capital inflow reduces discount rates in the debtor country by relaxing the intertemporal budget constraint (Obstfeld and Rogoff, 1996).

The effect of debt relief on cash flows also follows from the theory. If a country suffers from a debt overhang, then debt relief may increase the incentive to invest and raise expected future growth rates (Krugman, 1989; Sachs, 1989). To the extent that corporate cash flows are positively correlated with GDP, a higher GDP growth rate implies a faster growth trend for cash flows.

\section{VA. Is There a Change in Net Resource Transfers?}

Since debt relief may reduce discount rates by restoring positive net resource transfers to countries where it hat turned negative, the large positive ex-ante changes in market valuation should be associated with positive changes in the NRT. Panel A of Table V presents data on the Net Resource Transfer in event time. The table shows a clear pattern. The sign of the NRT changes twice for the Brady countries. In every one of the years from $[-18,-9]$ the median net resource transfer is positive for the Brady 
countries. In year -8 , roughly the time of the debt crisis, the NRT turns negative and remains so until after the Brady Plan. After the Brady Plan, net resource flows become positive for the rest of the sample.

Again, it is important to ask whether the reversal in the sign of the NRT in the Brady countries can be explained by a common shock. The evidence from the control group in Panel B of Table V suggests that this is not the case. The median level of NRT to the countries in the control group was positive for all but two years from 1970 to 2000 .

Panel B of Table $\mathrm{V}$ shows that the reversal in the direction of the net resource transfer is particularly striking for some individual Brady countries. In Brazil, for instance, after 10 consecutive years of negative resource transfers, the NRT turns positive in the year of the announcement of the Brady plan and remains positive for the rest of the sample. In 5 of 10 Brady countries with stock market data --Brazil, Jordan, Mexico, Philippines, and Venezuela -the NRT becomes positive within the first year of the Brady plan In Argentina and Ecuador, the NRT turned positive in the year preceding the plan. In Poland, the NRT turned positive in 1991, admittedly long before its debt relief plan was unveiled. However, following Poland's plan, there was a three-fold increase in the level of NRT. In fact, Peru is the only country from this group, which did not experience a change in NRT concomitant with its Brady plan. Peru is also the only country in the group, which did not experience a positive and significant stock market revaluation in anticipation of the plan.

The numbers in Panel B also demonstrate that debt relief without economic reform has only ephemeral success in restoring positive NRTs. After initially turning positive, the NRT becomes negative in 3 out of the 10 Brady countries with stock

\footnotetext{
${ }^{7}$ In Nigeria, the NRT turned positive two years after the Brady plan.
} 
markets: Nigeria, Philippines, and Venezuela. The last paragraph of Section IVB identifies Nigeria and the Philippines as non-reformers at the time of their Brady Plan. And Venezuela, according to Sachs and Warner (1995) significantly reversed its reforms after two years of successful implementation.

On the other hand, economic reform without debt relief is not sufficient to restore positive NRTs. We checked to see whether the NRT to Brady countries became positive following the economic reform dates in Table III. None of these reforms by themselves are successful in reversing the sign of the NRT. Only after the implementation of debt relief does the NRT turn positive. Again, this fact should not be interpreted to mean that economic reforms are unimportant. Indeed, the NRT remains positive only as long as countries sustain their economic reforms. Here is the point: While economic reforms are important for raising the productivity of capital, reforms by themselves may not be sufficient to overcome collective action problems.

Turning to Panel B, we see that Brady countries without stock markets do not systematically experience the reversal in the NRT that we see in the Brady stock market countries. The median NRT for the non-stock market Brady countries turned negative only once between $[-18,0]$. Although Panama and Uruguay have certainly experienced changes in the NRT following their Brady Plans, it is harder to make that assessment for the other countries. The net resource transfers to Bolivia, Bulgaria, Costa Rica, and the Dominican Republic have almost always been positive, even during the debt crisis years.

This pattern may suggest that debt relief for these poorer countries was not as effective as it was for the other countries for which dependable stock markets data were 
available. Section VI explores why this may be the case, but before doing so we now examine whether debt relief is associated with changes in growth.

\section{VB. Is There a Change in Growth?}

Since debt relief may increase expected future growth rates, positive ex-ante changes in market valuation should be associated with higher than normal future GDP growth. Figure 4 shows that countries grow faster following the Brady Plan. The graph plots the average deviation of the growth rate of per capita GDP from its country-specific mean in event time for all 16 Brady countries versus that of the control group. The message is clear. The Brady countries experience abnormally high growth rates in each of the five years following the Brady plan. There is no significant change in the growth rates of the control group.

\section{VC. Does the Stock Market Rationally Forecast the Changes?}

Table VI shows that the stock market revaluations appear to rationally forecast higher future NRTs. There is a strong correlation between the sign of the cumulative abnormal return on the stock market and the change in the sign of the NRT. In 9 of 10 countries, stock markets correctly predict the change in the sign of the NRT within the two years following the Brady Plan.

Next, Table VI shows that the stock market revaluations, which occur in anticipation of the Brady Plan, also appear to forecast higher future GDP growth outcomes. There is a strong correlation between the sign of the cumulative abnormal return on the stock market and the sign of the deviations of output growth from its long- 
run mean. In 9 of 10 countries, markets predicted the abnormal GDP growth in the year following the Brady Plan. In 9 of 10 countries, the markets predicted the positive cumulative abnormal GDP growth for the next two years, and similarly in 8 of the 10 countries for the next five years after the Brady Plan.

\section{Do the Results Suggest that the HIPC Initiative Will Work?}

Easterly (2001b) argues that debt relief is unlikely to promote investment, reform or growth in the HIPCs. We think that he is right. Yes, markets rise in anticipation of the Brady Plan. And ex-post data on net resource transfers and growth confirm the rationality of the markets' forecast. But there are vast differences between the Brady countries and the HIPCs.

Theory suggests that in order for a country to be a legitimate candidate for debt relief, it must satisfy two necessary (but not sufficient) conditions. First, the collective action problem must stand in the way of net capital inflows to that country. Second, the country must have a social infrastructure that is sufficiently well developed to ensure that net capital inflows will be channeled into growth-generating investment.

The data in Sections I through V suggest that the Brady countries meet both necessary conditions. In contrast, this section argues that the HIPC countries do not satisfy either. Specifically we demonstrate that: (1) Capital flows to the HIPC countries are not deterred by the collective action problem; (2) There has never been significant scope for profitable lending to the HIPC countries; and (3) The absence of profitable investment opportunities stems from a lack of social infrastructure. 


\section{VIA. The Collective Action Problem Does Not Deter Capital Flows to the HIPCs}

The Brady Plan worked because it alleviated the collective action problem, clearing the way for renewed and profitable lending to the Brady countries. In contrast, HIPC countries have never suffered from a negative NRT. Panel A of Table V (column 5) shows that the NRT to the HIPC countries has always been positive. If the goal of debt relief is to restore positive NRTs, then it is not clear how this policy will help a set of countries that have experienced an uninterrupted stream of positive net resource flows since 1971.

\section{VIB. There is Little Scope for Profitable Lending to the HIPC Countries}

Although things went sour in 1982, international lenders had expected to make money by lending to the Brady countries. Presumably, this is why they did so in the first place. In contrast, there has never been any such expectation for the HIPCs. Table VII throws the contrast into relief. As early as 1974 , loans to the private sector (private debt + foreign direct investment + portfolio equity) comprised almost half of the total net resource flow to the Brady stock market countries. On the other hand, international lending to the private sector has never been a significant fraction of the total net resource flows into HIPC countries. As a fraction of total inflows, loans to the private sector in the HIPC countries have never exceeded 10 percent and have been as low as 4 percent $\frac{8}{\text {. }}$

Furthermore, there has also been a shift in the composition of international lending to the Brady countries, away from the public sector and toward the private sector. Table VII shows that at the peak of the debt crisis (1985-89) grants plus public and publicly guaranteed debt accounted for 73 percent of the net resource transfer to the

\footnotetext{
${ }^{8}$ Table VIII provides a complete list of all the HIPC countries.
} 
Brady countries. By 1994, lending to the private sector - foreign direct investment (FDI), portfolio equity, and private debt- constituted the chief source of net resource flows. No such shift has taken place in the HIPC countries. In fact, the opposite has occurred-official flows and flows to the public sector have become more, not less, important. The role of grants has increased to the point where they now constitute the majority of the net resource flows to the HIPC countries.

\section{VIC. Poor Social Infrastructure Explains the Absence of Profitable Investment}

Recent advances in law and finance help explain the virtual absence of private capital flows to the HIPCs. The degree to which a country's law protects the legal rights of minority shareholders exerts a significant influence on that country's access to external finance, (La Porta, Lopez-de-Silanes, Shleifer and Vishny (LLSV) 1997, 1998, 2002; Shleifer and Vishny, 1997). If investors get poor protection they will stay away. Outside finance will dry up, and fewer resources will be available for growth (Dornbusch, 2000). This insight is germane to the present discussion. The median Brady country ranks lower than the median G7 country on every component of the LLSV index of investor protection: shareholder rights, creditor rights, efficiency of judicial system, rule of law, and rating of the accounting system.

Shleifer and Wolfenzon (2002) show that weaker investor protection lowers the marginal product of capital and can eliminate the incentive for capital to flow from rich to poor countries. According to their argument, the capital, which does flow to the Brady countries, pales in comparison to what we would see in a world where minority 
shareholders in the Brady countries enjoyed the same legal protection as their U.S. counterparts.

While the Brady countries rank low on the LLSV index, the HIPC countries do not even make the list. If private capital trickles to Brady countries because they fare poorly on the LLSV index, then woe to the HIPCs whose capital markets and investor protection laws are not sufficiently developed to even merit a ranking.

Having capital markets that are not sufficiently developed to make the LLSV ranking is probably correlated with having weak social institutions in general. In turn, social infrastructure can be a crucial factor in determining the level of human capital accumulation and the marginal product of capital (Kremer 1993). In other words, the rate of return to private lending in HIPC countries is low because they lack the institutional development that is necessary to create an environment where: (1) entrepreneurs can earn an economically fair rate of return on capital; and (2) lenders have an incentive to extend capital to the private sector.

We investigate this claim by using the Hall and Jones (1999) measure of social infrastructure to compare the HIPC and Brady countries. Hall and Jones construct their measure for 130 countries. The median G7 country ranks $14^{\text {th }}$; the median Brady country ranks $63^{\text {rd }}$; the median HIPC country ranks $102^{\text {nd }}$. Moreover, all of the G7 countries are in the highest $20^{\text {th }}$ percentile; all of the Brady countries, except for Nigeria and Dominican Republic, are in the highest $70^{\text {th }}$ percentile; 27 of the 38 HIPC countries with available data are in the lowest $30^{\text {th }}$ percentile.

We also compared HIPC and Brady countries using the average value of their score on the Heritage House Index of Economic Freedom from 1995 to 2002. The results 
are similar. Out of 161 countries, the median G7 country ranks $14^{\text {th }}$; the median Brady country ranks $59^{\text {th }}$; the median HIPC country ranks $110^{\text {th }}$. Moreover, all of the G7 countries are in the highest $20^{\text {th }}$ percentile; all the Brady countries, except for Bulgaria, are in the highest $60^{\text {th }}$ percentile; 24 of 39 HIPC countries with available data are in the lowest $40^{\text {th }}$ percentile over the same period.

It is interesting to note that a number of highly or moderately indebted countries closely resemble the Brady countries, but have received no consideration for debt relief. For example, consider Indonesia, Pakistan, Colombia, Jamaica, Malaysia, and Turkey. The median LLSV score for this group of six countries is 4.6 out of 10 . The median LLSV score for the Brady countries is 4.9. Similarly, the median country in the group of 6 ranks $61^{\text {st }}$ on the Hall and Jones (1999) measure of social infrastructure; the median Brady country ranks $63^{\text {rd }}$. Finally, the median country in the group of six ranks $58^{\text {th }}$ on the Heritage House Index of Economic Freedom; the Median Brady country ranks $59^{\text {th }}$. While we do not suggest that countries should receive debt relief based solely on their resemblance to Brady countries, the analysis suggests that debt relief for the group of six would constitute a much more efficient use of resources than debt relief for the HIPCs.

\section{Conclusion}

Largely because of the HIPC Initiative, debt relief has become synonymous with the poorest of poor countries. Developing countries that are equally indebted but have higher incomes do not receive any consideration for debt relief. For example, Easterly (2001b) shows that Latin American and Caribbean countries are on average more indebted than HIPC countries. Birdsall and Williamson (2002) call for extending the debt relief initiative to include a number of more developed emerging economies. Our 
results support their call and point to a cruel irony. Relatively developed but highly indebted emerging economies may be the most promising candidates for debt relief, but current efforts focus exclusively on HIPC countries where debt relief is least likely to achieve any efficiency gains. 


\section{References}

Arslanalp, Serkan, and Peter B. Henry. 2002. “All Debts Are Not Alike.” Mimeo, Stanford University.

Birdsall, Nancy and John Williamson. 2002. Delivering on Debt Relief: From IMF Gold to a New Aid Architecture. Washington, DC: Institute for International Economics.

Bruno, Michael, and William Easterly. 1996. Inflation's children: Tales of crises that beget reforms. American Economic Review, 86 (2), 213-217.

Bulow, Jeremy. 2002. First World Governments and Third World Debt. Brookings Papers on Economic Activity, No.1:2002, 229-55.

Bulow Jeremy, and Kenneth Rogoff. 1988. Cleaning up Third World Debt Without Getting Taken to the Cleaners. Journal of Economic Perspectives Vol. 4 No. 1, Winter 1990, pp.31-42

Cline, William. 1995. International Debt Reexamined. Washington, DC: Institute for International Economics.

Cline, William. 1997. "Debt Relief for Heavily Indebted Poor Countries: Lessons from the Debt Crisis of the 1980s." in External Finance for Developing Countries. Washington, DC: International Monetary Fund.

Collins, Susan M. 1990. Lessons from Korean economic growth. American Economic Review, 80, (2), 104-107.

Dornbush, Rudiger. 2000. Check the laws before you invest abroad, in Keys to Prosperity. Cambridge, MA: MIT Press.

Easterly, William. 2001a. The Elusive Quest for Growth. Cambridge, MA: MIT Press.

Easterly, William. 2001b. Debt Relief. Foreign Policy (November/December): 20-26.

Easterly, William. 2002. The Cartel of Good Intentions. Foreign Policy, (July/August): 40-49.

Frankel, Jeffrey. 1994. Introduction, in Jeffrey A. Frankel, ed.: The Internationalization of Equity Markets, (University of Chicago Press: Chicago and London), 231-71.

Hall, Robert, and Chad Jones. 1999. Why do some countries produce so much more output per worker than others? Quarterly Journal of Economics 114 (1): 84-116.

Henry, Peter B. 2000a. Stock market liberalization, economic reform, and emerging 
market equity prices, Journal of Finance, 55, 529-64.

Henry, Peter B. 2000b. Do stock market liberalizations cause investment booms? Journal of Financial Economics, 58, 301-34.

Henry, Peter B. 2002. Is Disinflation Good for the Stock Market? Journal of Finance, 57, 1617-48.

Jubilee2000. 1999. Hand-over of 17 million signatures to Chancellor Gerhard Schroeder in Cologne. http://www.jubilee2000uk.org/jubilee2000/news/petition2306.html (June).

Kho, Bong-Chan, Dong Lee and René M. Stulz. 2000. U.S. banks, crises, and bailouts: From Mexico to LTCM. American Economic Review, 90 (2),28-31.

Kremer, Michael. 1993. The O-Ring Theory of Economic Development. Quarterly Journal of Economics 108 (3): 551-575.

Kremer, Michael, and Seema Jayachandran. 2002. Odious Debt. Harvard University, Cambridge, MA. Preliminary (April).

Krugman, Paul. 1988. Financing Versus Forgiving a Debt Overhang. Journal of Development Economics 29 (November): 253-268.

Krugman, Paul. (1989). "Market-Based Debt Reduction Schemes." In Analytical Issues in Debt. edited by Jacob Frenkel, Michael Dooley, and P. Wickham. Washington: International Monetary Fund.

LaPorta, Rafael, Florencio Lopez-de-Silanes, Andrei Shleifer, and Robert Vishny (1997). "Legal Determinants of External Finance," Journal of Finance, 52, pp. 1131-50.

LaPorta, Rafael, Florencio Lopez-de-Silanes, Andrei Shleifer and Robert Vishny (1998). "Law and Finance," Journal of Political Economy, Vol. 106, pp. 1113-1155.

LaPorta, Rafael, Florencio Lopez-de-Silanes, Andrei Shleifer, and Robert Vishny (2002) "Investor Protection and Corporate Valuation," Journal of Finance, Forthcoming.

Mallaby, Sebastian. 2000. "Pro Bono.” Washington Post. 25 September.

Obstfeld, Maurice and Ken Rogoff (1996). Foundations of International Macroeconomics. MIT Press, Cambridge, MA.

O'Neill, Paul. 2002. "Caring Greatly and Succeeding Greatly: Producing Results in Africa," Remarks at Georgetown University in Washington, DC. June 52002. http://www.foreignpolicy.com/issue_julyaug_2002/oneill.html 
Sachs, Jeffrey, and Andrew Warner. 1995. "Economic Reform and the Process of Global Integration." Brookings Papers on Economic Activity 1: 1-95.

Sachs, Jeffrey. 1989. “The Debt Overhang of Developing Countries.” in Debt Stabilization and Development, edited by Guillermo A. Calvo, Ronald Findlay, Pentti Kouri, and Jorge Braga de Macedo. Oxford: Basil Blackwell.

Sachs, Jeffrey and Harry Huizinga. 1987. "U.S. Commercial Banks and the Developing Country Debt Crisis.” Brookings Papers on Economic Activity 2: 555-606.

Shleifer, Andrei and Robert Vishny (1997). "A Survey of Corporate Governance," Journal of Finance, Vol. 52, pp. 737-783

Shleifer, Andrei and Daniel Wolfenzon (2002). "Investor Protection and Equity Markets," Journal of Financial Economics, Forthcoming.

Stulz, René M., 1999a, International portfolio flows and security markets, in Martin Feldstein, ed.: International Capital Flows (University of Chicago Press, Chicago).

Summers, Lawrence. 2000. "Moving Forward with Millennial Debt Relief," Remarks at Reception to Celebrate HIPC, House Banking Committee Room United States Congress Washington, DC. February 12000. http://www.treas.gov/press/releases/ls363.htm

Tesar, Linda L., 1999, The role of equity in international capital flows, in Martin Feldstein, ed.: International Capital Flows (University of Chicago Press, Chicago).

Tesar, Linda L., and Ingrid M. Werner, 1998, The Internationalization of securities markets since the 1987 crash, in Robert E. Litan and Anthony M. Santomero Eds. Brookings Wharton Papers on Financial Services (Brookings Institution Press, Washington).

Tesar, Linda L., and Ingrid M. Werner, 1995, U.S. equity investment in emerging stock markets, World Bank Economic Review, 9, (4), 109-129.

The Vatican. 1998. Pope John Paul II's statement on debt relief given in Rome, at Saint Peter's, on 29 November 1998. Bull of Indiction of the Great Jubilee of the Year 2000 "Incarnationis Mysterium" (The Mystery of the Incarnation). http://www.vatican.va/jubilee_2000/docs/documents/hf_jpii_doc 30111998_bolla-jubilee_en.html (November).

World Bank. 1994. Trends in Developing Economies. Washington: World Bank. 
Williamson, John. 1994. The Political Economy of Policy Reform. Institute for International Economics. Washington, DC. 
Figure 1. Stock Prices Rise in Anticipation of Debt Relief

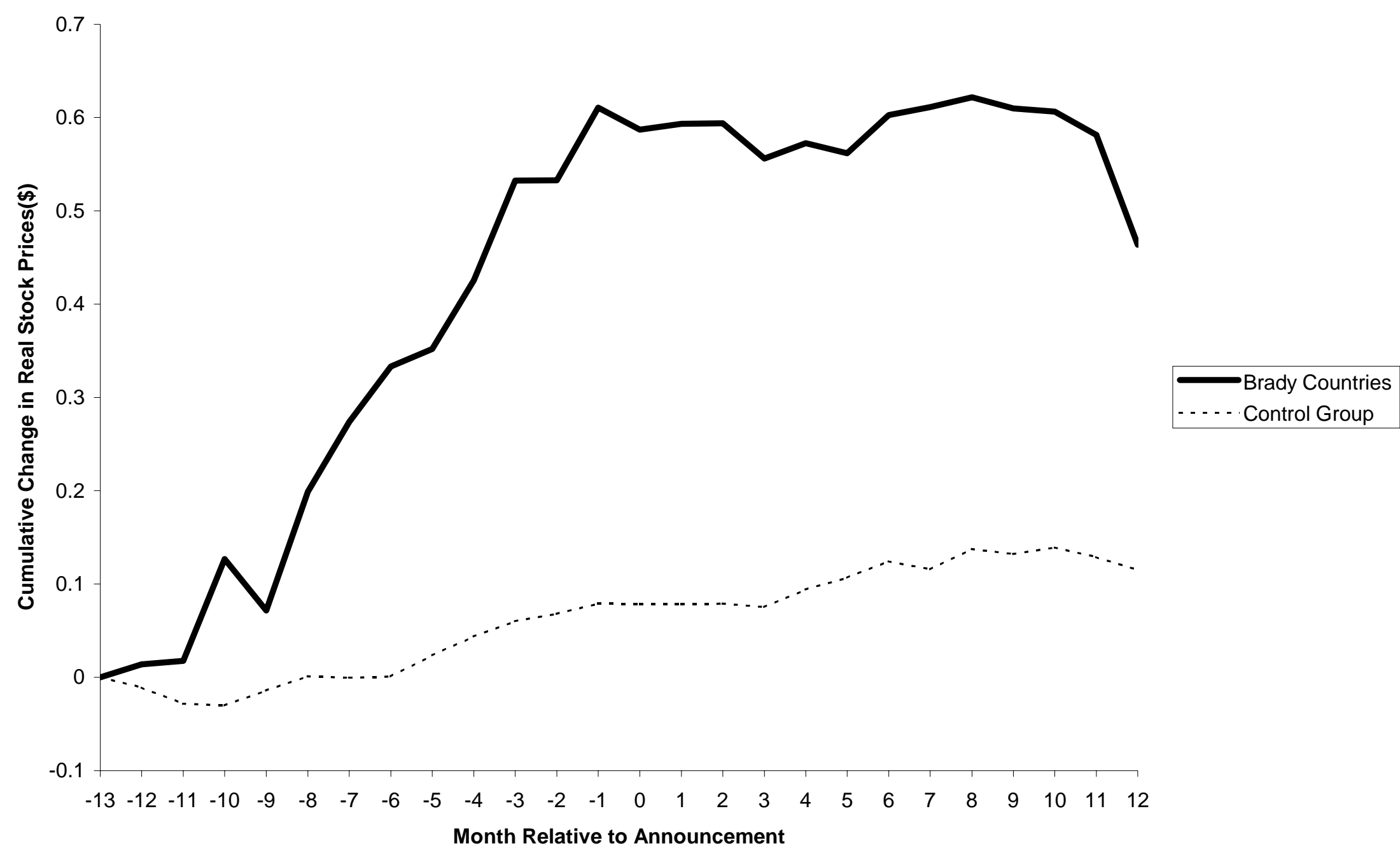

Figure 1. Stock prices rise in anticipation of debt relief. The variable on the y-axis is the continuously compounded abnormal percentage change. 0 is the month in which the debt relief plan was announced. The solid line is a plot of the cumulative residuals from a panel regression of the real dollar return from 10 Brady countries with stock market data available on a constant and 9 country-specific dummies. The dashed line is a plot of the cumulative residuals from a panel regression of the real dollar return from 16 control group countries on a constant and 15 country-specific dummies. 
Figure 2. Stock Prices Rise in Anticipation of Debt Relief

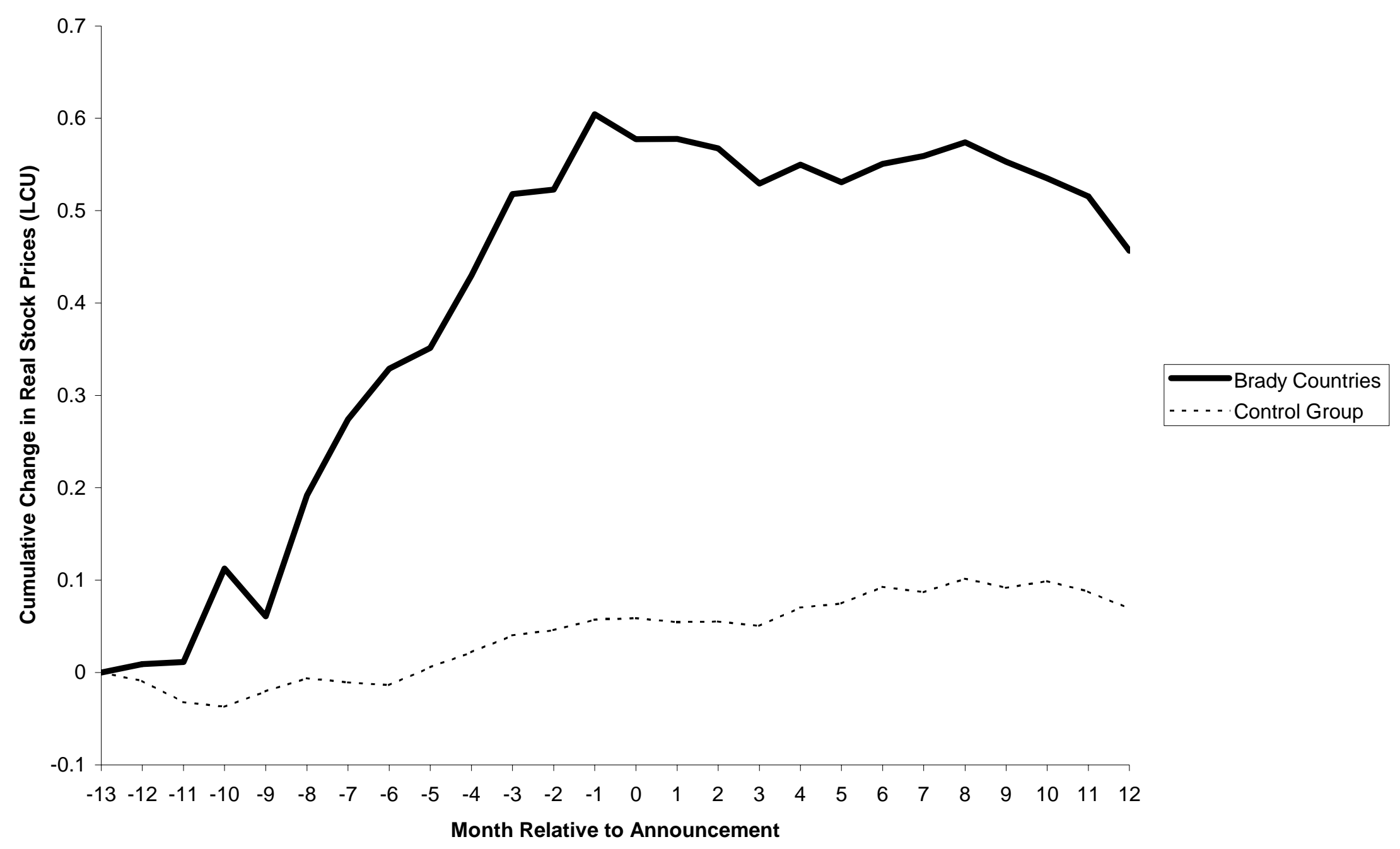

Figure 2. Stock prices rise in anticipation of debt relief. The variable on the y-axis is the continuously compounded abnormal percentage change. 0 is the month in which the debt relief plan was announced. The series in bold color is a plot of the cumulative residuals from a panel regression of the real local currency return from 10 Brady countries with stock market data available on a constant and 9 country-specific dummies. The series in light color is a plot of the cumulative residuals from a panel regression of the real local currency return from 16 control group countries on a constant and 15 country-specific dummies. 
Figure 3. The Stock Market and Brady Reformers vs Non-Reformers

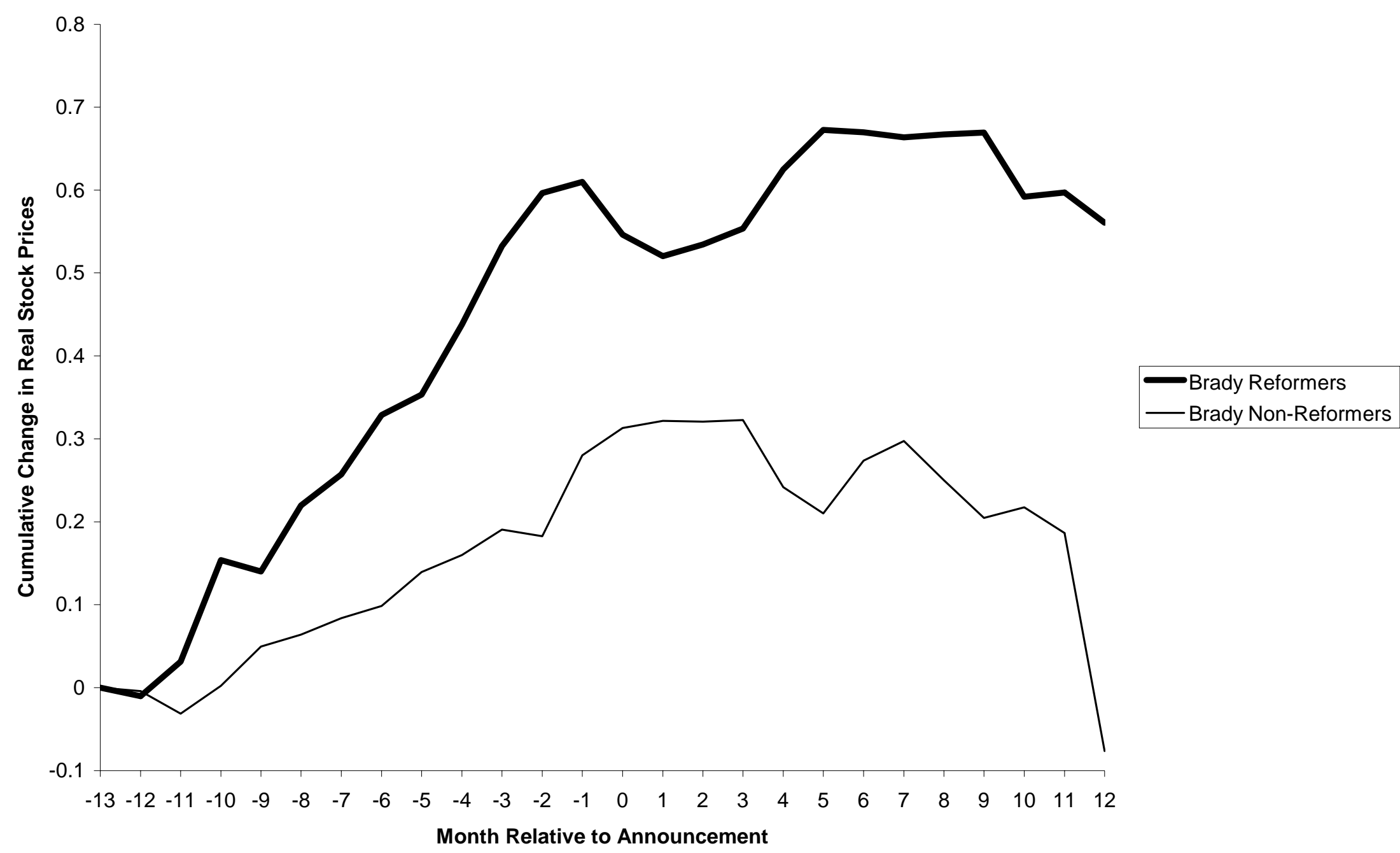

Figure 3. The stock market and Brady reformers versus non-reformers. The variable on the y-axis is the continuously compounded abnormal percentage change. 0 is the month in which the debt relief plan was announced. The series in bold color is a plot of the cumulative residuals from a panel regression of the real dollar return from 7 reformer Brady countries with stock market data available (Argentina, Brazil, Ecuador, Mexico, Peru, Poland, and Venezuela) on a constant and 6 country-specific dummies. The series in light color is a plot of the cumulative residuals from a panel regression of the real dollar return from 3 non-reformer Brady countries with stock market data available (Jordan, Nigeria, and Philippines) on a constant and 2 country-specific dummies. 
Figure 4. GDP Growth Increases Following Debt Relief

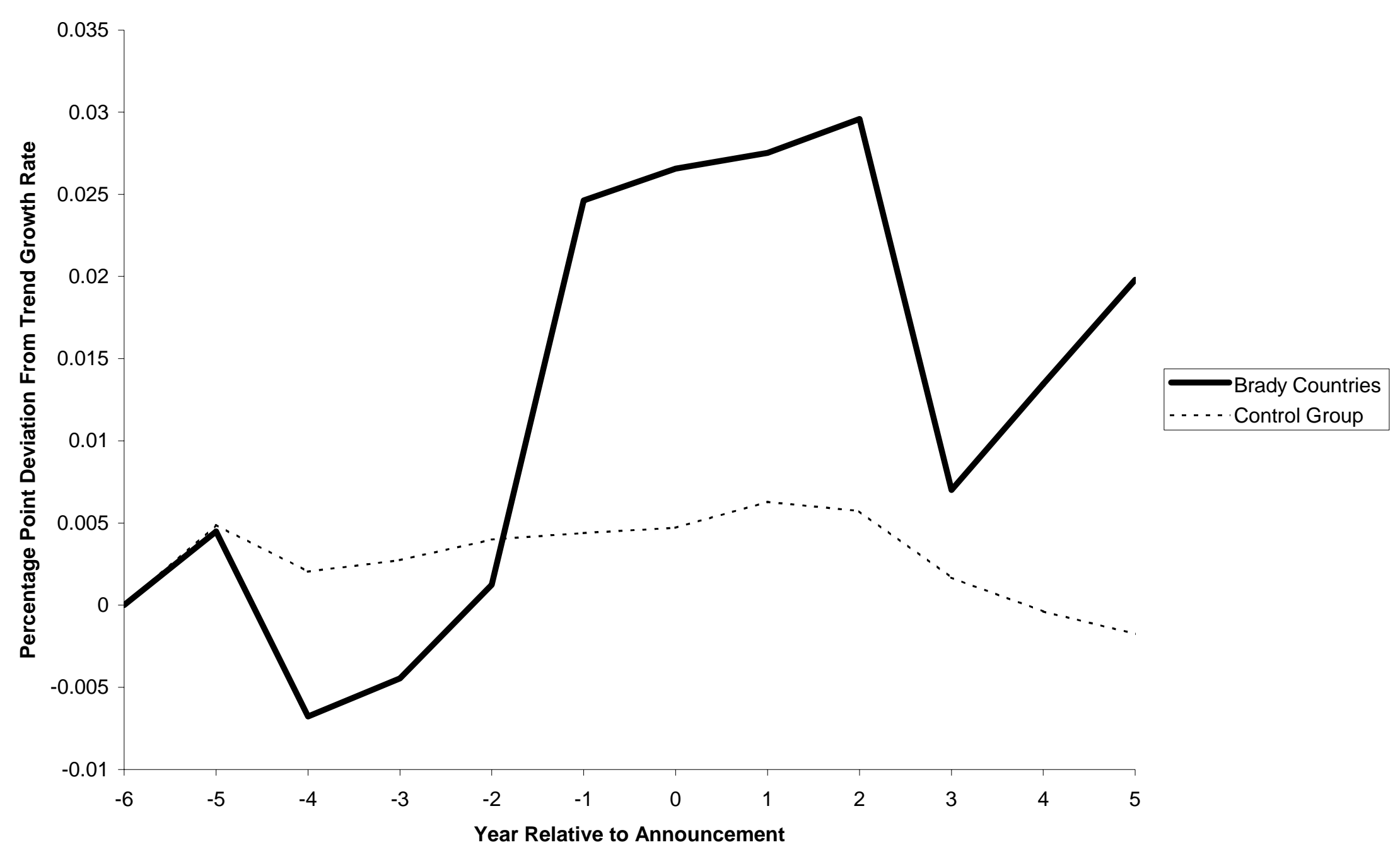

Figure 4. GDP growth increases following debt relief. The variable on the y-axis is the abnormal percentage deviation from the trend growth rate. 0 is the year in which the debt relief plan was announced. The series in bold color is a plot of the residuals from a panel regression of the real GDP growth rate from al 16 Brady countries on a constant and 15 country-specific dummies. The series in light color is a plot of the residuals from a panel regression of the real GDP growth rate from 16 control group countries on a constant and 15 country-specific dummies. 


\section{Table I. Universe of Countries in the Sample}

\begin{tabular}{|c|c|c|c|}
\hline $\begin{array}{c}\text { Brady Plan Countries: Date of } \\
\text { Announcement }\end{array}$ & $\begin{array}{c}\text { Stock Market } \\
\text { Data Available? }\end{array}$ & $\begin{array}{l}\text { Control Group } \\
\text { Countries }\end{array}$ & $\begin{array}{c}\text { Stock Market Data } \\
\text { Available? }\end{array}$ \\
\hline Argentina: April 1992 & Yes & Chile & Yes \\
\hline Brazil: August 1992 & Yes & China & Yes \\
\hline Ecuador: May 1994 & Yes & Colombia & Yes \\
\hline Jordan: June 1993 & Yes & Czech Republic & Yes \\
\hline Mexico: September 1989 & Yes & Greece & Yes \\
\hline Nigeria: March 1991 & Yes & Hungary & Yes \\
\hline Peru: October 1995 & Yes & India & Yes \\
\hline Philippines: August 1989 & Yes & Indonesia & Yes \\
\hline Poland: March 1994 & Yes & Korea & Yes \\
\hline Venezuela: June 1990 & Yes & Malaysia & Yes \\
\hline Bolivia: March 1993 & No & Pakistan & Yes \\
\hline Bulgaria: November 1993 & No & South Africa & Yes \\
\hline Costa Rica: November 1989 & No & Sri Lanka & Yes \\
\hline Dominican Republic: May 1993 & No & Thailand & Yes \\
\hline Panama: May 1995 & No & Turkey & Yes \\
\hline Uruguay: November 1990 & No & Zimbabwe & Yes \\
\hline Median growth & $\begin{array}{c}0.01 \\
(0.02)\end{array}$ & Median growth & $\begin{array}{c}0.03 \\
(0.01)\end{array}$ \\
\hline Median inflation & $\begin{array}{c}0.27 \\
(0.18)\end{array}$ & Median inflation & $\begin{array}{c}0.11 \\
(0.03)\end{array}$ \\
\hline
\end{tabular}

The first column lists all the countries in the Treatment group, i.e., the countries that signed Brady deals. The next column identifies the countries for which stock market data are available from the IFC Emerging Market Data Base or the Global Financial Data Base. In contrast, the last two columns list all the countries in the Control group, i.e. the countries that did not sign Brady deals and have had stock market data available as of 1994 from the IFC Emerging Market Data Base. The last two rows compare the Treatment and Control groups in terms of their historical GDP per capita growth and inflation rates from 1980 to 1999 . The standard deviation of each rate is given in parenthesis. 
Table II. Brady Countries Experience a Significant Increase in Market Valuation Before Debt Relief Announcements. The Control Countries Do Not. Panel A: White-Corrected OLS Estimates

\begin{tabular}{|c|c|c|c|c|c|c|c|c|c|c|c|c|}
\hline & \multicolumn{3}{|c|}{ Twelve-Month Window } & \multicolumn{3}{|c|}{ Nine-Month Window } & \multicolumn{3}{|c|}{ Six-Month Window } & \multicolumn{3}{|c|}{ Three-Month Window } \\
\hline & (1a) & $(1 \mathrm{~b})$ & (1c) & $(2 a)$ & $(2 \mathrm{~b})$ & $(2 \mathrm{c})$ & $(3 a)$ & $(3 b)$ & $(3 c)$ & $(4 a)$ & $(4 b)$ & $(4 c)$ \\
\hline $\begin{array}{l}\text { Right- } \\
\text { Hand-Side } \\
\text { Variables }\end{array}$ & Brady & Control & $\begin{array}{c}\text { Brady> } \\
\text { Control? }\end{array}$ & Brady & Control & $\begin{array}{c}\text { Brady> } \\
\text { Control? }\end{array}$ & Brady & Control & $\begin{array}{l}\text { Brady> } \\
\text { Control? }\end{array}$ & Brady & Control & $\begin{array}{c}\text { Brady> } \\
\text { Control? }\end{array}$ \\
\hline $\begin{array}{l}\text { Country- } \\
\text { Specific } \\
\text { Mean }\end{array}$ & $\begin{array}{l}.050 * * * \\
(.014)\end{array}$ & $\begin{array}{c}.004 \\
(.004)\end{array}$ & 0.001 & $\begin{array}{l}.050 * * * \\
(.015)\end{array}$ & $\begin{array}{l}.010 * * \\
(.005)\end{array}$ & 0.011 & $\begin{array}{l}.048 * * * \\
(.016)\end{array}$ & $\begin{array}{l}.014 * * * \\
(.005)\end{array}$ & 0.041 & $\begin{array}{c}.048 * \\
(.026)\end{array}$ & $\begin{array}{c}.009 \\
(.007)\end{array}$ & 0.15 \\
\hline $\begin{array}{l}\text { Constant } \\
\text { Mean }\end{array}$ & $\begin{array}{l}.049 * * * \\
(.013)\end{array}$ & $\begin{array}{c}.005 \\
(.004)\end{array}$ & 0.001 & $\begin{array}{l}.051 * * * \\
(.015)\end{array}$ & $\begin{array}{l}.009 * * \\
(.004)\end{array}$ & 0.005 & $\begin{array}{l}.049 * * * \\
(.016)\end{array}$ & $\begin{array}{l}.013 * * * \\
(.0045858)\end{array}$ & 0.022 & $\begin{array}{c}.045^{*} \\
(.025)\end{array}$ & $\begin{array}{c}.006 \\
(.007)\end{array}$ & 0.13 \\
\hline World & $\begin{array}{l}.047 * * * \\
(.014)\end{array}$ & $\begin{array}{c}.002 \\
(.005)\end{array}$ & 0.002 & $\begin{array}{l}.047 * * * \\
(.016)\end{array}$ & $\begin{array}{l}.009 * \\
(.005)\end{array}$ & 0.023 & $\begin{array}{l}.045 * * * \\
(.016)\end{array}$ & $\begin{array}{l}.014 * * * \\
(.005)\end{array}$ & 0.080 & $\begin{array}{c}.049 * \\
(.025)\end{array}$ & $\begin{array}{c}.004 \\
(.007)\end{array}$ & 0.09 \\
\hline US & $\begin{array}{l}.046 * * * \\
(.013)\end{array}$ & $\begin{array}{l}-.000 \\
(.005)\end{array}$ & 0.001 & $\begin{array}{l}.046 * * * \\
(.016)\end{array}$ & $\begin{array}{c}.007 \\
(.005)\end{array}$ & 0.018 & $\begin{array}{l}.043 * * * \\
(.016)\end{array}$ & $\begin{array}{l}.014 * * * \\
(.005)\end{array}$ & 0.076 & $\begin{array}{l}.048 * \\
(026)\end{array}$ & $\begin{array}{c}.004 \\
(.007)\end{array}$ & 0.10 \\
\hline LDC & $\begin{array}{l}.046 * * * \\
(.014)\end{array}$ & $\begin{array}{l}-.008 \\
(.006)\end{array}$ & 0.000 & $\begin{array}{l}.043 * * * \\
(.016)\end{array}$ & $\begin{array}{c}.001 \\
(.005)\end{array}$ & 0.011 & $\begin{array}{l}.039 * * \\
(.016)\end{array}$ & $\begin{array}{c}.005 \\
(.005)\end{array}$ & 0.0480 & $\begin{array}{l}.052 * * \\
(.024)\end{array}$ & $\begin{array}{c}.010 \\
(.007)\end{array}$ & 0.10 \\
\hline ALL & $\begin{array}{l}.047 * * * \\
(.014)\end{array}$ & $\begin{array}{l}-.007 \\
(.006)\end{array}$ & 0.000 & $\begin{array}{l}.044 * * * \\
(.016)\end{array}$ & $\begin{array}{c}.002 \\
(.005)\end{array}$ & 0.011 & $\begin{array}{l}.039 * * \\
(.016)\end{array}$ & $\begin{array}{c}.005 \\
(.005)\end{array}$ & 0.0451 & $\begin{array}{l}.052 * * \\
(.025)\end{array}$ & $\begin{array}{c}.009 \\
(.007)\end{array}$ & 0.09 \\
\hline
\end{tabular}

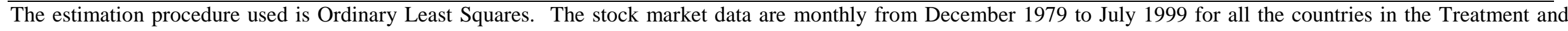

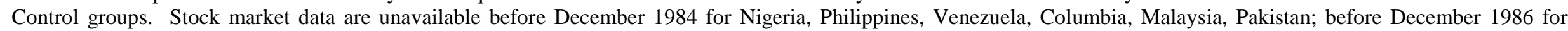

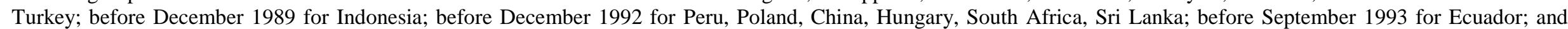

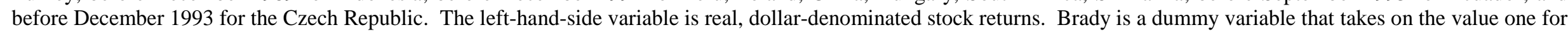

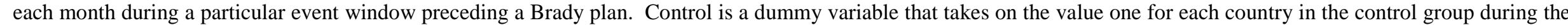

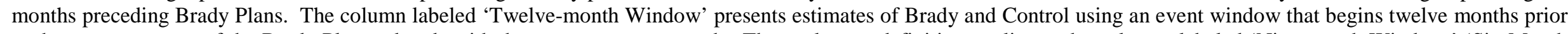

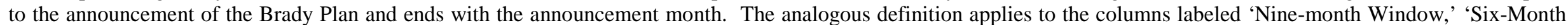

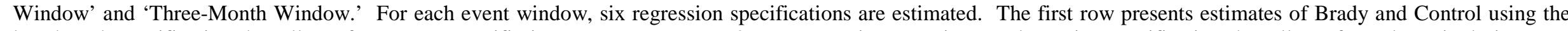

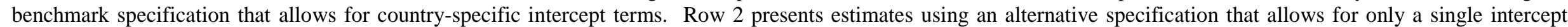

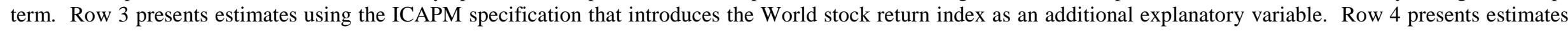

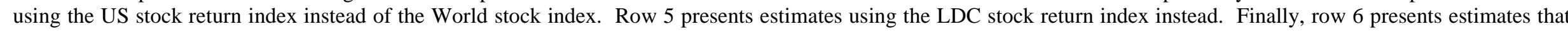

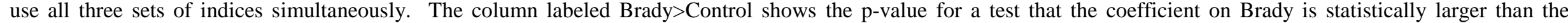

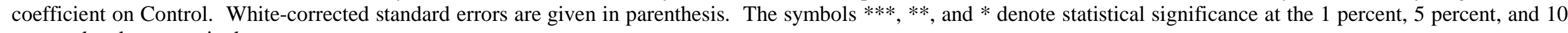
percent levels, respectively.
} 
Table II. Brady Countries Experience a Significant Increase in Market Valuation Before Debt Relief Announcements. The Control Countries Do Not. Panel B: FGLS Estimates

\begin{tabular}{|c|c|c|c|c|c|c|c|c|c|c|c|c|}
\hline & \multicolumn{3}{|c|}{ Twelve-Month Window } & \multicolumn{3}{|c|}{ Nine-Month Window } & \multicolumn{3}{|c|}{ Six-Month Window } & \multicolumn{3}{|c|}{ Three-Month Window } \\
\hline & (1a) & (1b) & (1c) & $(2 a)$ & $(2 b)$ & $(2 c)$ & (3a) & $(3 b)$ & $(3 c)$ & $(4 a)$ & (4b) & $(4 c)$ \\
\hline $\begin{array}{l}\text { Right- } \\
\text { Hand-Side } \\
\text { Variables }\end{array}$ & Brady & Control & $\begin{array}{c}\text { Brady> } \\
\text { Control? }\end{array}$ & Brady & Control & $\begin{array}{c}\text { Brady> } \\
\text { Control? }\end{array}$ & Brady & Control & $\begin{array}{c}\text { Brady> } \\
\text { Control? }\end{array}$ & Brady & Control & $\begin{array}{c}\text { Brady> } \\
\text { Control? }\end{array}$ \\
\hline $\begin{array}{l}\text { Country- } \\
\text { Specific } \\
\text { Mean }\end{array}$ & $\begin{array}{l}.041 * * * \\
(.010)\end{array}$ & $\begin{array}{c}.007 \\
(.004)\end{array}$ & 0.003 & $\begin{array}{l}.046 * * * \\
(.011)\end{array}$ & $\begin{array}{l}.012 * * \\
(.005)\end{array}$ & 0.005 & $\begin{array}{l}.051 * * * \\
(.013)\end{array}$ & $\begin{array}{l}.015^{* * * *} \\
(.005)\end{array}$ & 0.01 & $\begin{array}{c}.040 * \\
(.019)\end{array}$ & $\begin{array}{l}.014 * * \\
(.006)\end{array}$ & 0.20 \\
\hline $\begin{array}{l}\text { Constant } \\
\text { Mean }\end{array}$ & $\begin{array}{l}.038 * * * \\
(.010)\end{array}$ & $\begin{array}{l}.008^{*} \\
(.004)\end{array}$ & 0.003 & $\begin{array}{l}.044 * * * \\
(.011)\end{array}$ & $\begin{array}{l}.011^{* * *} \\
(.004)\end{array}$ & 0.005 & $\begin{array}{l}.049 * * * \\
(.013)\end{array}$ & $\begin{array}{l}.015^{* * * *} \\
(.006)\end{array}$ & 0.01 & $\begin{array}{l}.039 * * \\
(.019)\end{array}$ & $\begin{array}{l}.014 * * \\
(.006)\end{array}$ & 0.21 \\
\hline World & $\begin{array}{l}.033 * * * \\
(.011)\end{array}$ & $\begin{array}{c}.003 \\
(.005)\end{array}$ & 0.015 & $\begin{array}{l}.039 * * * \\
(.013)\end{array}$ & $\begin{array}{c}.009 * \\
(.005)\end{array}$ & 0.026 & $\begin{array}{l}.045^{* * *} \\
(.015)\end{array}$ & $\begin{array}{l}.013 * * * \\
(.005)\end{array}$ & 0.04 & $\begin{array}{l}.042^{* *} \\
(.022)\end{array}$ & $\begin{array}{l}.012 * * \\
(.006)\end{array}$ & 0.17 \\
\hline US & $\begin{array}{l}.032 * * * \\
(.011)\end{array}$ & $\begin{array}{c}.002 \\
(.005)\end{array}$ & 0.013 & $\begin{array}{l}.038 * * * \\
(.013)\end{array}$ & $\begin{array}{c}.008 \\
(.005)\end{array}$ & 0.023 & $\begin{array}{l}.045^{* * *} \\
(.015)\end{array}$ & $\begin{array}{l}.013 * * * \\
(.005)\end{array}$ & 0.03 & $\begin{array}{l}.042 * * \\
(.022)\end{array}$ & $\begin{array}{c}.010 * \\
(.006)\end{array}$ & 0.14 \\
\hline LDC & $\begin{array}{l}.034 * * * \\
(.012)\end{array}$ & $\begin{array}{l}-.005 \\
(.005)\end{array}$ & 0.002 & $\begin{array}{l}.037 * * * \\
(.013)\end{array}$ & $\begin{array}{c}.001 \\
(.005)\end{array}$ & 0.010 & $\begin{array}{l}.043 * * * \\
(.015)\end{array}$ & $\begin{array}{c}.005 \\
(.005)\end{array}$ & 0.01 & $\begin{array}{l}.043 * * \\
(.021)\end{array}$ & $\begin{array}{c}.007 \\
(.006)\end{array}$ & 0.11 \\
\hline ALL & $\begin{array}{l}.034 * * * \\
(.012)\end{array}$ & $\begin{array}{l}-.005 \\
(.005)\end{array}$ & 0.002 & $\begin{array}{l}.036 * * * \\
(.013)\end{array}$ & $\begin{array}{l}.001 \\
(.005)\end{array}$ & 0.011 & $\begin{array}{l}.043 * * * \\
(.015)\end{array}$ & $\begin{array}{l}.005 \\
(.005)\end{array}$ & 0.02 & $\begin{array}{l}.042 * * \\
(.022)\end{array}$ & $\begin{array}{c}.006 \\
(.006)\end{array}$ & 0.10 \\
\hline
\end{tabular}

The estimation procedure is Feasible Generalized Least Squares. The stock market data are monthly from December 1979 to July 1999 for all the countries in the Treatment and Control groups. Stock market data are unavailable before December 1984 for Nigeria, Philippines, Venezuela, Columbia, Malaysia, Pakistan; before December 1986 for Turkey; before December 1989 for Indonesia; before December 1992 for Peru, Poland, China, Hungary, South Africa, Sri Lanka; before September 1993 for Ecuador; and before December 1993 for the Czech Republic. The left-hand-side variable is real, dollar-denominated stock returns. Brady is a dummy variable that takes on the value one for each month during a particular event window preceding a Brady plan. Control is a dummy variable that takes on the value one for each country in the control group during the months preceding Brady Plans. The column labeled 'Twelve-month Window' presents estimates of Brady and Control using an event window that begins twelve months prior to the announcement of the Brady Plan and ends with the announcement month. The analogous definition applies to the columns labeled 'Nine-month Window, 'Six-Month Window' and 'Three-Month Window.' For each event window, six regression specifications are estimated. The first row presents estimates of Brady and Control using the benchmark specification that allows for country-specific intercept terms. Row 2 presents estimates using an alternative specification that allows for only a single intercept term. Row 3 presents estimates using the ICAPM specification that introduces the World stock return index as an additional explanatory variable. Row 4 presents estimates using the US stock return index instead of the World stock index. Row 5 presents estimates using the LDC stock return index instead. Finally, row 6 presents estimates that use all three sets of indices simultaneously. The column labeled Brady>Control shows the p-value for a test that the coefficient on Brady is statistically larger than the coefficient on Control. Standard errors are given in parenthesis. The symbols $* * *, * *$, and $*$ denote statistical significance at the 1 percent, 5 percent, and 10 percent levels, respectively. 
Table III. IMF Programs and Major Economic Reforms in Brady Countries

\begin{tabular}{|c|c|c|c|c|c|}
\hline Country & Brady Plan & $\begin{array}{l}\text { Stabilization (IMF } \\
\text { Program) }\end{array}$ & Trade Liberalization & Privatization & $\begin{array}{l}\text { Capital Account } \\
\text { Liberalization }\end{array}$ \\
\hline Brazil & August 1992 & January 1992 (SB) & April 1990 & July 1990 & March 1988 \\
\hline Bulgaria & November 1993 & NA & NA & 1991 & NA \\
\hline $\begin{array}{l}\text { Dominican } \\
\text { Republic }\end{array}$ & May 1993 & NA & Closed & 1999 & NA \\
\hline Ecuador & May 1994 & May 1994 & January 1991 & February 1993 & January 1993 \\
\hline Jordan & June 1993 & May 1994 (EFF) & 1965 & January 1995 & January 1978 \\
\hline Panama & May 1995 & & NA & 1990 & NA \\
\hline Peru & October 1995 & March 1993 (EFF) & March 1991 & March 1991 & $\begin{array}{l}\text { NA (Open Before 95) } \\
\text { Investibility index }\end{array}$ \\
\hline Philippines & August 1989 & May $1989(\mathrm{EFF})$ & November 1988 & June 1988 & May 1986 \\
\hline Poland & March 1994 & August 1994 (SB) & 1990 & $1990 *$ & 1990 \\
\hline Uruguay & November 1990 & & 1990 & 1990 & NA \\
\hline Venezuela & June 1990 & June 1989 (EFF) & May $1989 * *$ & April 1991 & January 1990 \\
\hline
\end{tabular}

This table lists the announcement dates of major economic events for the countries in the Treatment group. The first column identifies these countries. The second column lists the month and year of each country's Brady Plan. These dates are obtained from Cline (1995), Lexis/Nexis, and various issues of the Economist Intelligence Unit. The third column lists IMF plans that are announced shortly preceding or following Brady Plans. These dates are obtained from Henry (2002) and various issues of the IMF Annual Reports. A Standby agreement with the IMF is noted as SB and an Extended Fund Facility agreement is noted as EFF. The next three columns list the dates of the beginnings of major economic reforms. The trade liberalization dates are obtained from Sachs and Werner (1995). The privatization dates are obtained from the Privatization Data Base maintained by the World Bank. The capital account liberalization dates are obtained from Henry (2000). *Poland switched to a market economy in 1990, simultaneously setting up a stock market and opening up to foreign investment. **Venezuela reversed its trade liberalization reforms in 1993. 
Table IV, After Controlling for Other Reforms, Brady Countries Experience a Significant Increase in Market Valuation Before Debt Relief Announcements. The Control Countries Do not. Panel A: White-Corrected OLS Estimates

World-Return Model

\begin{tabular}{|c|c|c|c|c|c|c|c|c|}
\hline & $\begin{array}{c}\text { Twelve-Month } \\
\text { Window }\end{array}$ & $\begin{array}{l}\text { Nine-Month } \\
\text { Window }\end{array}$ & $\begin{array}{l}\text { Six-Month } \\
\text { Window }\end{array}$ & $\begin{array}{l}\text { Three-Month } \\
\text { Window }\end{array}$ & $\begin{array}{c}\text { Twelve-Month } \\
\text { Window }\end{array}$ & $\begin{array}{l}\text { Nine-Month } \\
\text { Window }\end{array}$ & $\begin{array}{l}\text { Six-Month } \\
\text { Window }\end{array}$ & $\begin{array}{l}\text { Three-Month } \\
\text { Window }\end{array}$ \\
\hline Brady & $\begin{array}{l}.048 * * * \\
(.012)\end{array}$ & $\begin{array}{l}.049 * * * \\
(.013)\end{array}$ & $\begin{array}{l}.047 * * * \\
(.016)\end{array}$ & $\begin{array}{l}.054 * * \\
(.023)\end{array}$ & $\begin{array}{l}.048 * * * \\
(.012)\end{array}$ & $\begin{array}{l}.048 * * * \\
(.013)\end{array}$ & $\begin{array}{l}.046 * * * \\
(.015)\end{array}$ & $\begin{array}{l}.053 * * \\
(.022)\end{array}$ \\
\hline Control & $\begin{array}{l}.003 \\
(.005)\end{array}$ & $\begin{array}{l}.008 \\
(.005)\end{array}$ & $\begin{array}{l}.012 * * \\
(.006)\end{array}$ & $\begin{array}{l}.009 \\
(.008)\end{array}$ & $\begin{array}{l}.005 \\
(.005)\end{array}$ & $\begin{array}{l}.009 * * \\
(.005)\end{array}$ & $\begin{array}{l}.013 * * * \\
(.005)\end{array}$ & $\begin{array}{l}.010 \\
(.007)\end{array}$ \\
\hline P-Value of & 0.000 & 0.003 & 0.03 & 0.07 & 0.000 & 0.004 & 0.040 & 0.070 \\
\hline
\end{tabular}

Brady >

Control?

Privatize

$-.013$

(.016)

.009

(.016)

$\begin{array}{lll}.011 & .011 & .022 \\ (.016) & (.018) & (.028) \\ & & \\ -.004 & -.006 & -.052 \\ (.018) & (.022) & (.033) \\ & & \\ .025 & .051 * * & .094 * * * \\ (.018) & (.021) & (.033)\end{array}$

.005
$(.014)$
-.011
$(.016)$
.013
$(.016)$

.005
$(.014)$
-.011
$(.016)$
.013
$(.016)$

.010

(.015)

$-.001$

(.018)

.029

(.018)

.012
$(.018)$
-.002
$(.021)$
$.057 * * *$
$(.021)$

\begin{abstract}
The estimation procedure is Ordinary Least Squares; White-corrected standard errors are given in parenthesis. The stock market data are monthly from December 1979 to July 1999 for all the countries in the Treatment and Control groups. Stock market data are unavailable before December 1984 for Nigeria, Philippines, Venezuela, Columbia, Malaysia, Pakistan; before December 1986 for Turkey; before December 1989 for Indonesia; before December 1992 for Peru, Poland, China, Hungary, South Africa, Sri Lanka; before September 1993 for Ecuador; and before December 1993 for the Czech Republic. The left-hand-side variable is real, dollar-denominated stock returns. Brady is a dummy variable that takes on the value one for each month during a particular event window preceding a Brady plan. Four different event windows are utilized. The column labeled 'Twelve-month Window' presents estimates of Brady and Control using an event window that begins twelve months prior to the announcement of the Brady Plan and ends with the announcement month. The analogous definition applies to the columns labeled 'Nine-month Window,' 'Six-Month Window' and 'Three-Month Window.' Control is a dummy variable that takes on the value one for each country in the control group during the months preceding Brady Plans. Privatize, Trade, and Liberalize are dummy variables that take on the value one during the event window preceding a privatization, trade liberalization and stock market liberalization respectively. For each event window, two regression specifications are estimated. The World column presents estimates of Brady, Control, Privatize, Trade, and Liberalize using the ICAPM specification that introduces the World stock return index as an additional explanatory variable. The Constant Mean column presents estimates using the specification that allows for only a single intercept term. The column labeled Brady>Control shows the p-value for a test that the coefficient on Brady is statistically larger than the coefficient on Control. . The symbols $* * * * *$, and $*$ denote statistical significance at the 1 percent, 5 percent, and 10 percent levels, respectively.
\end{abstract}


Table IV. After Controlling for Other Reforms, Brady Countries Experience a Significant Increase in Market Valuation Before Debt Relief Announcements. The Control Countries Do Not. Panel B: FGLS Estimates

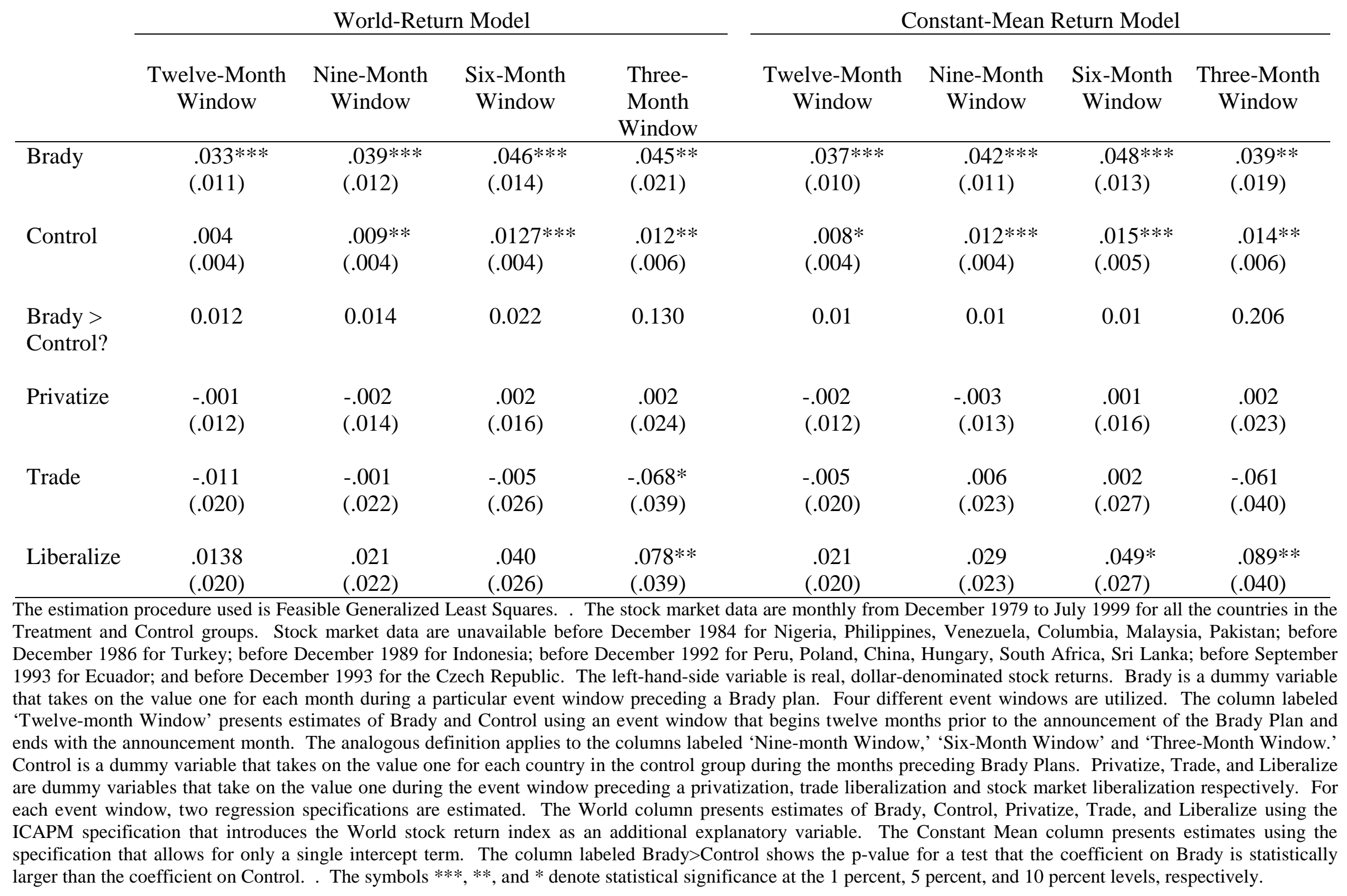


Table V. The Brady Plan Reverses the Sign of the Net Resource Transfer (Millions of US\$) in the Brady Stock Market Countries. Panel A: Group Medians

\begin{tabular}{|c|c|c|c|c|}
\hline $\begin{array}{l}\text { Year in Event } \\
\text { Time }\end{array}$ & $\begin{array}{l}\text { Brady Stock } \\
\text { Market Countries }\end{array}$ & Control Group & $\begin{array}{l}\text { Brady Non-Stock } \\
\text { Market Countries }\end{array}$ & $\begin{array}{l}\text { Highly-Indebted } \\
\text { Poor Countries }\end{array}$ \\
\hline-18 & 87 & 91 & 58 & 13 \\
\hline-17 & 10 & 143 & 69 & 19 \\
\hline-16 & 123 & 116 & 142 & 25 \\
\hline-15 & 382 & 104 & 87 & 25 \\
\hline-14 & 285 & 124 & 27 & 61 \\
\hline-13 & 495 & 220 & 152 & 65 \\
\hline-12 & 1371 & 100 & 129 & 53 \\
\hline-11 & 1063 & 347 & 155 & 78 \\
\hline-10 & 847 & 505 & 54 & 103 \\
\hline-9 & 297 & 648 & 237 & 151 \\
\hline-8 & -43 & 594 & 100 & 134 \\
\hline-7 & 146 & 403 & 103 & 119 \\
\hline-6 & -419 & 330 & 78 & 123 \\
\hline-5 & -1679 & 529 & 87 & 119 \\
\hline-4 & -833 & 189 & 37 & 118 \\
\hline-3 & -228 & 84 & -40 & 117 \\
\hline-2 & -767 & -71 & 49 & 143 \\
\hline-1 & -578 & -10 & 80 & 171 \\
\hline 0 & -283 & 187 & 58 & 202 \\
\hline 1 & -54 & 366 & -46 & 223 \\
\hline 2 & 2372 & 998 & 188 & 252 \\
\hline 3 & 1216 & 1173 & 48 & 259 \\
\hline 4 & 1124 & 2675 & 197 & 262 \\
\hline 5 & 2267 & 2197 & 407 & 229 \\
\hline
\end{tabular}

Net resource transfers are equal to net resource flows minus interest payments on long-term loans and foreign direct investment profits. The first column lists the years in event time. The number ' 0 ' represents the year in which its Brady Plan was announced. For Control group countries and Highly-Indebted Poor Countries (HIPC), 0 represents 1989. The next four columns show the progression of net resource transfers in event time to the following groups of countries: the Control group, the Brady Stock market group, the Brady Non-Stock market group, and the HIPC countries. The Control group countries are displayed in Table I. The Brady Stock market countries are the countries in the Treatment group with available stock market data as displayed in Table I. The Brady Non-Stock market countries are the remaining countries of the Treatment group. The HIPC countries are displayed in Table VIII. The data on NRT are obtained from World Bank’s Global Development Finance Data Base. 
Table V. The Net Resource Transfer (Millions of US\$). Panel B: Individual Brady Stock Market Countries.

\begin{tabular}{|c|c|c|c|c|c|c|c|c|c|c|}
\hline $\begin{array}{c}\text { Year Event } \\
\text { Time }\end{array}$ & Argentina & Brazil & Ecuador & Jordan & Mexico & Nigeria & Peru & Philippines & Poland & Venezuela \\
\hline-18 & -86 & 5586 & 10 & 466 & 100 & -725 & 211 & -42 & NA & -535 \\
\hline-17 & -568 & 3968 & 484 & 471 & 132 & -519 & -328 & 123 & NA & -1036 \\
\hline-16 & 613 & 4618 & 382 & 490 & 1188 & -468 & -406 & -20 & NA & -1760 \\
\hline-15 & -358 & 4572 & 285 & 547 & 1747 & -640 & -580 & 295 & NA & -527 \\
\hline-14 & 495 & 6869 & 349 & 1342 & 2418 & -411 & -479 & 510 & NA & -428 \\
\hline-13 & 3372 & 1858 & 704 & 1348 & 3112 & 1303 & 712 & 986 & 2346 & 1393 \\
\hline-12 & 1593 & -844 & -905 & 1272 & 3285 & 830 & 854 & 807 & 1500 & 1442 \\
\hline-11 & 4436 & 1867 & -432 & 1055 & 2433 & -1354 & 440 & 639 & 213 & 2700 \\
\hline-10 & 3231 & -410 & -207 & 997 & 1136 & 758 & -84 & 547 & -546 & 47 \\
\hline-9 & -1197 & -3614 & -399 & 777 & 3043 & 1445 & 167 & 489 & -324 & -253 \\
\hline-8 & -3454 & -1074 & 28 & 687 & 7490 & 700 & 263 & 729 & -317 & -1475 \\
\hline-7 & -1330 & -6550 & 85 & 867 & 542 & -1426 & 153 & 561 & -1437 & -923 \\
\hline-6 & -2971 & -7100 & -63 & 745 & -5658 & -2290 & 203 & 865 & -1067 & -2550 \\
\hline-5 & -2629 & -7066 & 18 & 496 & -8666 & -514 & 243 & 72 & -1152 & -2486 \\
\hline-4 & -1729 & -7229 & -251 & 808 & -9452 & 95 & -206 & 224 & -202 & -3856 \\
\hline-3 & -1412 & -8948 & -354 & 853 & -6443 & -1180 & 228 & -263 & 2753 & -4276 \\
\hline-2 & -2571 & -3952 & -377 & 410 & -1485 & 1414 & 2155 & -779 & 1163 & -3483 \\
\hline-1 & 528 & -496 & 231 & -70 & -7443 & -1799 & 4460 & -655 & 2180 & -1927 \\
\hline 0 & 2917 & 5026 & 67 & -222 & -7553 & -1473 & 3723 & -175 & 2176 & -2283 \\
\hline 1 & 11975 & 10913 & 144 & 39 & 5364 & -2277 & 3946 & 51 & 6437 & 797 \\
\hline 2 & 7794 & 3469 & 278 & 333 & 4798 & 351 & 2080 & -272 & 4804 & 206 \\
\hline 3 & 6122 & 7217 & 555 & 70 & 1699 & 631 & 1618 & -844 & 6169 & -1280 \\
\hline 4 & 13205 & 18474 & -169 & 610 & 13114 & -372 & 2160 & 2374 & 7943 & -1836 \\
\hline 5 & 12793 & 24250 & 156 & 208 & 11235 & -691 & 550 & 2293 & 8317 & -1811 \\
\hline
\end{tabular}

The net resource transfer (NRT) to individual Brady Stock market countries in event time. The Brady Stock market countries are the countries in the Treatment group with available stock market data as displayed in Table V, Panel A. The data on NRT are obtained from World Bank's Global Development Finance Data

Base. 
Table V. The Net Resource Transfer (Millions of US\$). Panel C: Individual Non-Stock Market Brady Countries

\begin{tabular}{|c|c|c|c|c|c|c|}
\hline & Bolivia & Bulgaria & $\begin{array}{l}\text { Costa } \\
\text { Rica }\end{array}$ & $\begin{array}{c}\text { Dominican } \\
\text { Republic }\end{array}$ & Panama & Uruguay \\
\hline-18 & 167 & NA & 42 & 58 & 168 & 11 \\
\hline-17 & 213 & NA & 45 & 69 & 417 & -14 \\
\hline-16 & 300 & NA & 58 & 142 & 41 & 213 \\
\hline-15 & 214 & NA & 87 & 88 & -174 & -19 \\
\hline-14 & 151 & NA & 163 & 27 & -140 & 21 \\
\hline-13 & 214 & NA & 152 & 267 & 119 & 66 \\
\hline-12 & 147 & 350 & 244 & 111 & -59 & 99 \\
\hline-11 & 44 & 495 & 152 & 157 & -126 & 390 \\
\hline-10 & -112 & 374 & 110 & -1 & -269 & 395 \\
\hline-9 & -94 & 740 & 234 & 240 & -349 & 254 \\
\hline-8 & -166 & 746 & 137 & 161 & -224 & 63 \\
\hline-7 & 244 & 1277 & 49 & -21 & -42 & 156 \\
\hline-6 & 223 & 1026 & -131 & 92 & 63 & -254 \\
\hline-5 & 186 & 364 & 10 & 95 & 80 & -264 \\
\hline-4 & 270 & 245 & 41 & 34 & -44 & -113 \\
\hline-3 & 199 & -434 & -76 & 64 & -167 & -5 \\
\hline-2 & 614 & 144 & 97 & -35 & 1 & -252 \\
\hline-1 & 492 & 100 & 61 & -51 & 236 & -165 \\
\hline 0 & 349 & 108 & 36 & -32 & 79 & -396 \\
\hline 1 & 454 & 441 & -21 & -129 & -71 & -164 \\
\hline 2 & 853 & -64 & 105 & 271 & 1509 & 103 \\
\hline 3 & 912 & -68 & -90 & -108 & 1320 & 165 \\
\hline 4 & 1212 & 147 & -104 & 163 & 852 & 232 \\
\hline 5 & 1196 & 331 & 0 & 608 & 482 & 65 \\
\hline
\end{tabular}

The net resource transfer (NRT) to Brady Non-Stock market countries in event time. The Brady Non-Stock market countries are the countries in the Treatment group without available stock market data as displayed in Table V, Panel; B. The data on the NRT are obtained from the World Bank's Global Development Finance Data Base. 
Table VI. The Stock Market Forecasts Future Changes in the Net Resource Transfer and GDP Growth

\begin{tabular}{|c|c|c|c|c|c|c|c|}
\hline & $\begin{array}{l}\text { Stock Market } \\
\text { Deviation } \\
\text { Anticipating } \\
\text { Debt Relief }\end{array}$ & $\begin{array}{l}\text { Change in } \\
\text { the Net } \\
\text { Resource } \\
\text { Transfer }\end{array}$ & $\begin{array}{l}\text { Growth } \\
\text { Deviation: } \\
\text { Year [0] }\end{array}$ & $\begin{array}{l}\text { Growth } \\
\text { Deviation: } \\
\text { Year [+1] }\end{array}$ & $\begin{array}{c}\text { Growth } \\
\text { Deviation: } \\
\text { Year [+2] }\end{array}$ & $\begin{array}{c}\text { Cumulative } \\
\text { Growth } \\
\text { Deviation } \\
\text { Year }[0,+2]\end{array}$ & $\begin{array}{l}\text { Cumulative } \\
\text { Growth } \\
\text { Deviation: } \\
\text { Year }[0,+5]\end{array}$ \\
\hline Argentina & + & + & + & + & + & + & + \\
\hline Brazil & + & + & - & + & + & + & + \\
\hline Ecuador & + & + & + & + & + & + & - \\
\hline Jordan & + & + & - & + & + & + & + \\
\hline Mexico & + & + & + & + & + & + & + \\
\hline Nigeria & + & + & + & + & + & + & + \\
\hline Peru & - & $\begin{array}{l}\text { No change } \\
\text { in sign }\end{array}$ & + & + & + & + & + \\
\hline Philippines & + & + & + & + & - & + & + \\
\hline Poland & + & $\begin{array}{l}\text { No change } \\
\text { in sign* }\end{array}$ & + & + & + & + & + \\
\hline Venezuela & + & + & + & + & + & + & + \\
\hline \multicolumn{8}{|c|}{$\begin{array}{l}\text { This table presents the correlation between increases in market valuation before Brady Plan announcements and changes in net resource transfers an } \\
\text { GDP growth afterwards. The first column lists the Brady Stock market countries. The Brady Stock market countries are the countries in the Treatmen } \\
\text { group with available stock market data as displayed in Table I. The second column identifies the countries that experienced abnormal stock marke } \\
\text { returns over the } 12 \text { months preceding their Brady Plan announcements. The third column identifies the countries that experienced changes fron } \\
\text { negative NRT to positive NRT in the year preceding or during the two years following the announcement. The fourth column identifies the countrie } \\
\text { that experienced abnormal GDP growth in the year of the announcement. The fifth and sixth columns identify those that experienced abnorma } \\
\text { growth in the first and second year after the announcement. Finally, the seventh and eight columns identify the countries that experienced abnorma } \\
\text { cumulative GDP growth during the two and five years following the announcement of the Brady Plan. The + sign denotes positive identification of } \\
\text { country. * Following the Brady Plan in Poland there is no change in the sign of NRT, but the level of NRT almost triples. }\end{array}$} \\
\hline
\end{tabular}


Table VII. The Composition of Net Resource Flows into HIPC, Brady, and Control Group Countries: 1970-1994.

\begin{tabular}{|c|c|c|c|c|c|c|c|c|c|c|}
\hline & \multirow{2}{*}{$\begin{array}{c}1970-74 \\
\text { Millions } \\
\text { of US\$ }\end{array}$} & \multirow[b]{2}{*}{$\begin{array}{c}\text { Percent of } \\
\text { Total }\end{array}$} & \multirow{2}{*}{$\begin{array}{c}1975-79 \\
\text { Millions } \\
\text { of US\$ }\end{array}$} & \multirow[b]{2}{*}{$\begin{array}{c}\text { Percent of } \\
\text { Total }\end{array}$} & \multirow{2}{*}{$\begin{array}{c}1980-84 \\
\text { Millions } \\
\text { of US\$ }\end{array}$} & \multirow[b]{2}{*}{$\begin{array}{l}\text { Percent } \\
\text { of Total }\end{array}$} & \multirow{2}{*}{$\begin{array}{c}\text { 1985-89 } \\
\text { Millions } \\
\text { of US\$ }\end{array}$} & \multirow[b]{2}{*}{$\begin{array}{l}\text { Percent } \\
\text { of Total }\end{array}$} & \multirow{2}{*}{$\begin{array}{c}\text { Millions } \\
\text { of US\$ }\end{array}$} & \multirow[b]{2}{*}{$\begin{array}{l}\text { Percent } \\
\text { of Total }\end{array}$} \\
\hline & & & & & & & & & & \\
\hline \multicolumn{11}{|c|}{ (2) } \\
\hline Net Resource Flows & 61 & 100.0 & 172 & 100.0 & 269 & 100.0 & 305 & 100.0 & 412 & 100.0 \\
\hline Public Debt & 39 & 64.6 & 111 & 64.5 & 176 & 65.4 & 158 & 51.9 & 120 & 29.2 \\
\hline Private Debt & 3 & 4.2 & 3 & 1.8 & 5 & 1.9 & -1 & -0.3 & 0 & -0.1 \\
\hline FDI & 4 & 5.9 & 12 & 7.0 & 11 & 4.0 & 14 & 4.4 & 50 & 12.2 \\
\hline PortfolioEquity & 0 & 0.0 & 0 & 0.0 & 0 & 0.0 & 0 & 0.0 & 5 & 1.1 \\
\hline Grants & 15 & 25.2 & 46 & 26.7 & 77 & 28.7 & 134 & 44.0 & 237 & 57.6 \\
\hline \multicolumn{11}{|l|}{ Brady } \\
\hline Net Resource Flows & 530 & 100.0 & 1562 & 100.0 & 1938 & 100.0 & 722 & 100.0 & 2645 & 100.0 \\
\hline Public Debt & 264 & 49.8 & 1045 & 66.9 & 1346 & 69.4 & 443 & 61.4 & 309 & 11.7 \\
\hline Private Debt & 133 & 25.1 & 219 & 14.0 & 212 & 11.0 & -177 & -24.5 & 466 & 17.6 \\
\hline FDI & 116 & 21.9 & 253 & 16.2 & 305 & 15.7 & 365 & 50.6 & 982 & 37.1 \\
\hline Portfolio Equity & 0 & 0.0 & 0 & 0.0 & 2 & 0.1 & 6 & 0.9 & 708 & 26.8 \\
\hline Grants & 17 & 3.3 & 46 & 2.9 & 74 & 3.8 & 83 & 11.6 & 180 & 6.8 \\
\hline \multicolumn{11}{|l|}{ Control Group } \\
\hline Net Resource Flows & 356 & 100.0 & 825 & 100.0 & 1612 & 100.0 & 1693 & 100.0 & 4853 & 100.0 \\
\hline Public Debt & 242 & 67.9 & 556 & 67.3 & 1055 & 65.4 & 1012 & 59.8 & 1278 & 26.3 \\
\hline Private Debt & 42 & 11.8 & 104 & 12.6 & 236 & 14.6 & 62 & 3.7 & 736 & 15.2 \\
\hline FDI & 35 & 9.9 & 91 & 11.0 & 206 & 12.8 & 443 & 26.2 & 1981 & 40.8 \\
\hline Portfolio Equity & 0 & 0.0 & 0 & 0.0 & 3 & 0.2 & 47 & 2.8 & 665 & 13.7 \\
\hline Grants & 37 & 10.4 & 75 & 9.0 & 113 & 7.0 & 129 & 7.6 & 193 & 4.0 \\
\hline
\end{tabular}


Table VIII. The Highly Indebted Poor Countries (HIPCs)

\begin{tabular}{|c|c|c|c|}
\hline Angola & Cote d'Ivoire & Madagascar & Sierra Leone \\
\hline Benin & Ethiopia & Malawi & Somalia \\
\hline Bolivia & The Gambia & Mali & Sudan \\
\hline Burkina Faso & Ghana & Mauritania & Tanzania \\
\hline Burundi & Guinea & Mozambique & Togo \\
\hline Cameroon & Guinea-Bissau & Myanmar & Uganda \\
\hline $\begin{array}{l}\text { Central African } \\
\text { Republic }\end{array}$ & Guyana & Nicaragua & Vietnam \\
\hline Chad & Honduras & Niger & Yemen \\
\hline Comoros & Kenya & Rwanda & Zambia \\
\hline $\begin{array}{l}\text { Democratic Republic of } \\
\text { Congo }\end{array}$ & Lao PDR & Sao Tome and Principe & \\
\hline Republic of Congo & Liberia & Senegal & \\
\hline
\end{tabular}

